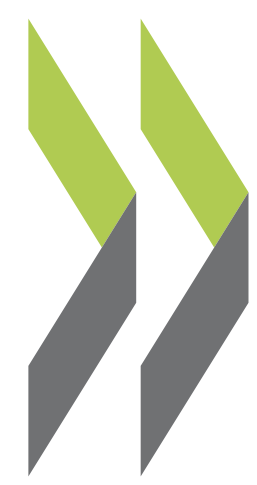

OECD Economics Department Working Papers No. 1587

\title{
Improving school results and equity in compulsory education in Sweden
}

\section{Jon Pareliussen,}

Christophe André,

Hyunjeong Hwang 


\title{
ECONOMICS DEPARTMENT
}

\section{IMPROVING SCHOOL RESULTS AND EQUITY IN COMPULSORY EDUCATION IN SWEDEN}

\section{ECONOMICS DEPARTMENT WORKING PAPERS No. 1587}

\section{By Jon Pareliussen, Christophe André and Hyunjeong Hwang}

\begin{abstract}
OECD Working Papers should not be reported as representing the official views of the OECD or of its member countries. The opinions expressed and arguments employed are those of the author(s).

Authorised for publication by Isabell Koske, Deputy Director, Country Studies Branch, Economics Department.
\end{abstract}

All Economics Department Working Papers are available at www.oecd.org/eco/workingpapers.

JT03456123 
OECD Working Papers should not be reported as representing the official views of the OECD or of its member countries. The opinions expressed and arguments employed are those of the author(s).

Working Papers describe preliminary results or research in progress by the author(s) and are published to stimulate discussion on a broad range of issues on which the OECD works.

Comments on Working Papers are welcomed, and may be sent to the Economics Department, OECD, 2 rue André-Pascal, 75775 Paris Cedex 16, France, or by e-mail to eco.contact@oecd.org.

All Economics Department Working Papers are available at www.oecd.org/eco/workingpapers.

On 25 May 2018, the OECD Council invited Colombia to become a Member. At the time of preparation the deposit of Colombia's instrument of accession to the OECD Convention was pending and therefore Colombia does not appear in the list of OECD Members and is not included in the OECD zone aggregates.

This document and any map included herein are without prejudice to the status of or sovereignty over any territory, to the delimitation of international frontiers and boundaries and to the name of any territory, city or area.

The statistical data for Israel are supplied by and under the responsibility of the relevant Israeli authorities. The use of such data by the OECD is without prejudice to the status of the Golan Heights, East Jerusalem and Israeli settlements in the West Bank under the terms of international law.

(C) OECD (2019)

You can copy, download or print OECD content for your own use, and you can include excerpts from OECD publications, databases and multimedia products in your own documents, presentations, blogs, websites and teaching materials, provided that suitable acknowledgment of OECD as source and copyright owner is given. All requests for commercial use and translation rights should be submitted to rights@oecd.org 


\begin{abstract}
RESUMÉ
Improving school results and equity in compulsory education in Sweden

Swedish school results declined for two decades following a series of reforms in the early 1990s decentralising the school system and introducing choice, competition and management by objectives. The general aims and direction of reform were not destined to lower results, but weaknesses of reform design and implementation, against the backdrop of a deep recession, likely contributed to falling outcomes. Residential segregation and the current model of competition and choice increase school segregation and likely reduce equality of opportunity. A coherent set of reforms should strengthen central government institutions, rebuild a regional governance structure and increasingly target funding to pupils' needs. Better steering of competition and school choice implies ensuring that grades fairly represent pupils' skills and knowledge, that municipalities increasingly take the socio-economic mix of pupils into account in entry and investment decisions, and that entry and expansion of private schools are better coordinated to counter school segregation. Teaching needs to become more attractive to raise the quality of recruitment to the profession and to address current and future teacher shortages by improving teacher education, strengthening continuous learning and instigating more cooperation, feedback and support between colleagues.

This Working Paper relates to the 2019 OECD Economic Survey of Sweden (http://www.oecd.org/economy/sweden-economic-snapshot/).
\end{abstract}

JEL Classification: H44, H75, I21, I28

Keywords: Sweden, education, competition, governance

\title{
Améliorer les résultats scolaires et l'équité dans l'enseignement scolaire en Suède
}

Les résultats scolaires ont diminué pendant deux décennies en Suède, à la suite d'une série de réformes entreprises au début des années 90 qui décentralisaient le système scolaire et introduisaient le choix, la concurrence et la gestion par objectifs. Les objectifs généraux et l'orientation des réformes n'étaient pas voués à réduire les résultats, mais les faiblesses de la conception et de la mise en œuvre des réformes, dans le contexte d'une profonde récession, ont probablement contribué à la chute des résultats. La ségrégation résidentielle et le modèle actuel de concurrence et de choix augmentent la ségrégation scolaire et réduisent probablement l'égalité des chances. Un ensemble cohérent de réformes devrait renforcer les institutions du gouvernement central, reconstruire une structure de gouvernance régionale et davantage cibler le financement en fonction des besoins des élèves. Un meilleur guidage de la concurrence et du choix des établissements implique de veiller à ce que les notes représentent objectivement les compétences et les connaissances des élèves, que les municipalités tiennent davantage compte de la composition socioéconomique des élèves dans les décisions d'entrée et d'investissement, et que l'entrée et l'expansion des écoles privées soient mieux coordonnées pour contrecarrer la ségrégation scolaire. L'enseignement doit devenir plus attrayant pour améliorer la qualité du recrutement dans la profession et pour remédier à la pénurie actuelle et future d'enseignants en améliorant l'éducation des enseignants, en renforçant la formation continue et en suscitant davantage de coopération, de retour d'information et de soutien entre collègues.

Ce Document de travail se rapporte à l'Étude économique de la Suède 2019 (http://www.oecd.org/fr/economie/suede-en-un-coup-d-oeil/).

Classification JEL : H44, H75, I21, I28

Mots clefs : Suède, éducation, compétition, gouvernance 


\section{Table of Contents}

Improving school results and equity in compulsory education in Sweden.......................................... 5

Demographic pressures on public services differ between cities and countryside ............................. 6

Declining quality and equity in schools challenge Sweden's growth model ................................... 10

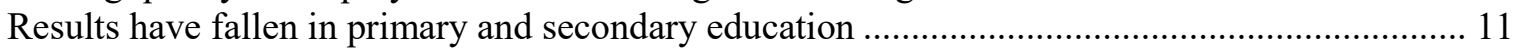

Pupils' performance depends on who their parents are ................................................................ 12

Reasons for falling performance are complex, but likely linked to 1990s reforms ......................... 15

Decentralisation and competition reforms rested on shaky foundations ...................................... 18

Reforms to take back control helped, but also created new issues................................................ 19

A reform consensus is taking shape, but some issues remain contentious....................................... 20

A coherent reform programme should address governance, choice and teachers ............................. 22

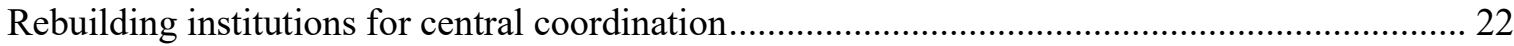

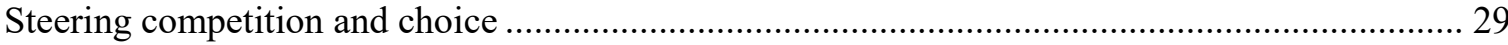

Improving teacher education and the attractiveness of the profession ............................................. 36

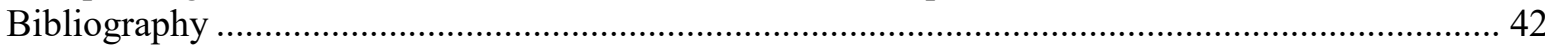

Figures

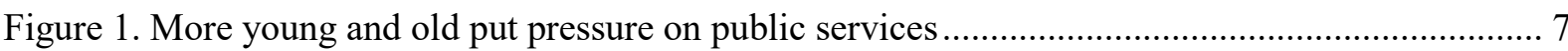

Figure 2. Sweden faces teacher shortages, notably in rural areas ................................................... 9

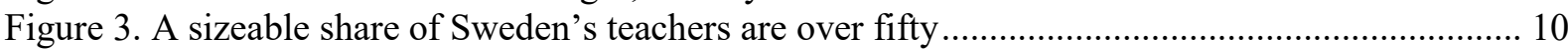

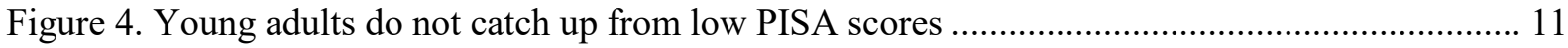

Figure 5. A rapid decline in school results may have bottomed out.................................................... 12

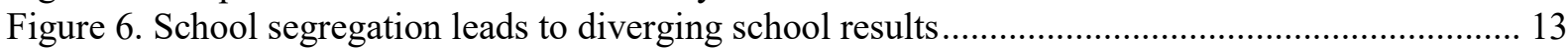

Figure 7. Peer effects are stronger for children with weaker socio-economic backgrounds ................. 14

Figure 8. School results are more polarised in Stockholm and Malmö .............................................. 15

Figure 9. Geographical result differences largely reflect socio-economic backgrounds...................... 15

Figure 10. Adult skills are highest among cohorts graduating from compulsory school around the

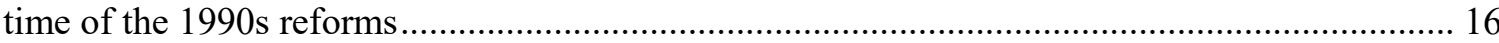

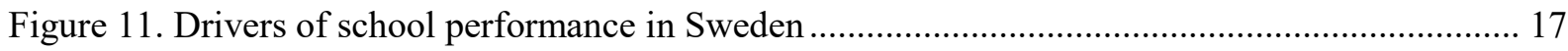

Figure 12. Higher spending on education does not necessarily improve results................................. 23

Figure 13. Schools with weak socio-economic backgrounds lack materials and teachers ..................... 24

Figure 14. Most decisions are taken at school or municipal level..................................................... 27

Figure 15. The scale of publicly funded for-profit schools is unique in Sweden ................................ 30

Figure 16. A rising share of pupils attend publicly-funded private schools ......................................... 31

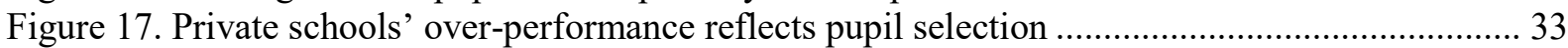

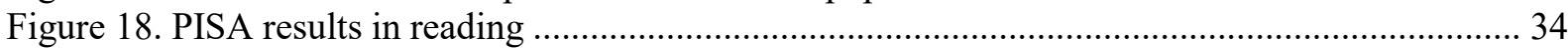

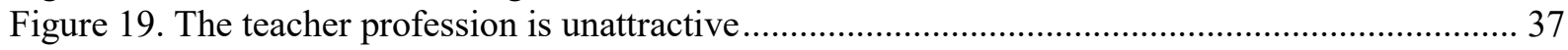

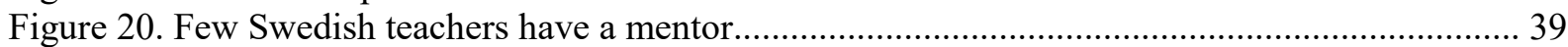

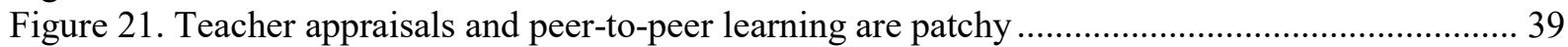

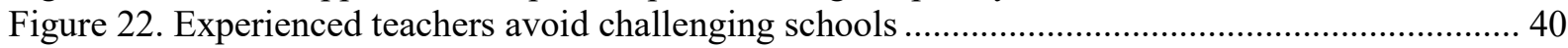

Boxes

Box 1. Organisation of primary and secondary education in Sweden.................................................. 8

Box 2. Drivers of school performance in a panel regression set-up ................................................ 17

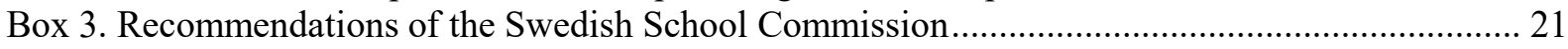

Box 4. Essunga municipality: school failure was turned into success in three years ............................ 28

Box 5. Competition and school choice in the Netherlands............................................................... 33 


\title{
Improving school results and equity in compulsory education in Sweden
}

\author{
By Jon Pareliussen, Christophe André and Hyunjeong Hwang ${ }^{1}$
}

Sweden enjoys among the highest levels of income per capita and well-being in the OECD and the highest employment rate in the European Union. The economy has proved very resilient to the crisis hurting the global economy, thanks to sound macroeconomic management and a strong knowledge base. As such, Sweden is also less vulnerable than many other OECD countries to losses of jobs due to digitalisation.

However, shortages of skilled labour appear in some sectors, partly due to years of vigorous economic growth, but also to structural reasons. The number of pupils in Swedish schools is set to increase in the coming years, while recruitment to the profession is insufficient and the existing teacher population is ageing. Recruiting enough quality personnel is challenging after years of declining status of the profession. Teacher scarcity is highest in remote parts of the country, as youth with higher education tend to migrate to the cities. These demographic pressures further challenge a Swedish school system where results and equity have declined in recent decades.

Swedish schools entered the 1990s from a position of strength, as one of the top performers in early international school surveys. However, school results declined for two decades following a series of reforms in the early 1990s. Reforms to decentralise the school system, and to introduce choice, competition and management by objectives likely played a role, not because of their general direction (several successful school systems in the OECD are decentralised, with some choice, management by objectives and private provision (OECD, $\left.2017_{[1]}\right)$ ), but because of concrete issues of design and implementation (Gustafsson, Sörlin and Vlachos, 2016 $[2]$; School Commission, 2017 $\left.7_{[3]}\right)$. Furthermore, these reforms coincided with cost savings in the public sector triggered by the 1990s economic crisis. The latest vintage of the OECD Programme for International Student Assessment (PISA) showed an improvement, but Sweden's educational performance only climbed back to close to the OECD average. Furthermore, inequalities across pupils and schools are widening, and children increasingly attend schools with pupils from similar backgrounds. Even though there is no unambiguous evidence of peer effects in Swedish schools, there is a clear risk that these trends deprive pupils of equal opportunities. Furthermore, they may reduce the average performance of the school system to the extent pupils from weak backgrounds lose more from segregation than strong pupils gain (OECD, 2016 ${ }_{[4]}$; OECD, 2017 ${ }_{[5]}$; Skolverket, $\left.2018_{[6]}\right)$. The Swedish School Commission, with representation from a broad set of stakeholders, presented a range of reform proposals, but some of the more important ones remain politically difficult, and some require further enquiry (School Commission, 2017 ${ }_{[3]}$ ).

This paper describes and analyses the challenges facing Sweden's school system with a focus on primary and lower secondary education, but with relevance also for upper secondary schools. A companion paper provides an econometric analysis of the performance of Swedish secondary schools (André, Pareliussen and Hwang, 2019 $9_{[7]}$ ). The complexity of the school system calls for a cautious approach to reform, with

\footnotetext{
${ }^{1}$ The authors would like to thank Vincent Koen, Zuzana Smidova (OECD Economics Department), Jeffrey Mo (OECD Education Directorate), Henrik Jordahl, Gabriel Heller Sahlgren, Jonas Vlachos for useful comments and suggestions on earlier versions of this paper, and Sisse Nielsen for excellent editorial assistance. Special thanks go to the Government of Sweden for facilitating the survey process, and to ministries, agencies and institutions who met with the OECD team during two missions to Sweden and provided invaluable comments and inputs.
} 
experimentation and implementation designed to allow for quantitative research and evaluations. A set of recommendations is outlined, focussing on three main areas of improvement:

- A recentralisation of some aspects of education policy is recommended, based on evidence that the decentralisation of the 1990s has not delivered the expected results. A centrally set non-binding minimum funding norm, integrated with the national system for income equalisation between municipalities would better align school funding with needs and equity objectives. A strengthened regional arm of the central government governance structure should enhance cooperation, improve skills development, promote continuous quality improvements, and instil accountability at every level.

- Competition and school choice need to be steered to reduce school segregation and deliver for the public good by ensuring that grades fairly represent pupils' skills and knowledge, loosening the proximity principle for school entry and introducing a wider set of evaluation criteria for private providers planning to open new, expand or to take over existing schools.

- Teaching needs to become more attractive to recruit and retain high quality teachers. Better teacher education with a stronger research base and more teaching practice, clearer career paths and more cooperation, feedback and support between colleagues would help. Teachers should face incentives to progress, perform and take on challenging tasks, coupled with clear accountability for key outcomes.

\section{Demographic pressures on public services differ between cities and countryside}

Demographic developments are putting pressure on public services, especially education, health and long-term care. Both the number of Swedes aged under 20 and aged over 70 will rise by about 300000 by 2025. Population is ageing less rapidly in Sweden than in most other high-income countries, including those of Northern Europe. Net immigration added almost a percentage point to annual average population growth in 2014-17, and mostly consists of humanitarian and family reunion migrants. Asylum applications fell back to normal levels of slightly below 30000 per year after the peak of 163000 in 2015. Almost a quarter of the population was either foreign-born or had two foreign-born parents in 2017 (Statistics Sweden, 2018 $[8]$; OECD, 2017 $[5]$ ). Partly as a result of high immigration and higher fertility among immigrants than natives, the share of young people is growing fast. The number of children and elderly for each working-age person is set to increase more than in the average high-income and Northern Europe country, albeit less than in the average European country over 2015-25 (Figure 1). 
Figure 1. More young and old put pressure on public services

Projected increase in the dependency ratio 2015-25, percentage points

12

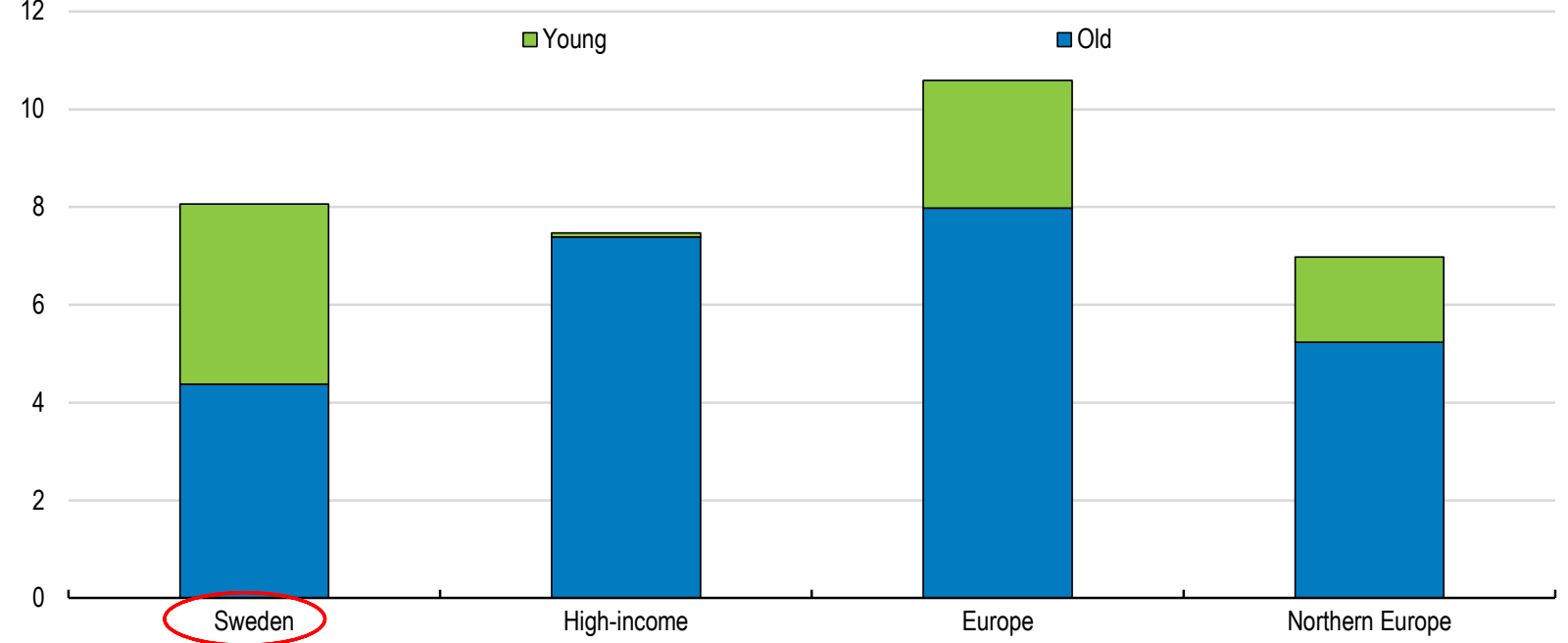

Note: The dependency ratio relates the number of younger (0-19 years old) and older persons (65 years or over) to the working-age population (20-64 years old). The numbers are based on the medium variant of the United Nations population projections. High-income countries are defined on the basis of 2016 gross national income per capita data from the World Bank. Northern Europe includes the Baltic and Nordic countries, Ireland and the United Kingdom.

Source: United Nations, World Population Prospects: The 2017 Revision.

StatLink 젶ㄴ http://dx.doi.org/10.1787/888933943968

Sweden has strong public finances, with a government debt-to-GDP ratio below $40 \%$, and a budget surplus for the past four years, despite increases in welfare spending and immigration-related costs and a reduction of taxes on pensions. Financial resources are available within an overall prudent fiscal policy to address the needs of the elderly and to invest in the future through education and integration policies.

Sweden is one of the most decentralised countries in the OECD. The provision of public services is largely organised by its 20 county councils (landsting) and 290 municipalities (kommuner). Government responsibilities organised on a county basis are either governed through the county administrative board (länsstyrelse) or by national government agencies with different regional organisations, which is the case for example for the Swedish Police (Polismyndigheten), Swedish Public Employment Service (Arbetsförmedlingen) and Swedish Social Insurance Agency (Försäkringskassan). The county councils oversee public healthcare, public transport and culture services. Municipalities are responsible for childcare and pre-school, primary and secondary schools (Box 1). Other important municipal responsibilities include social services, elderly care, support to people with disabilities, health and environment issues, emergency services (except police), infrastructure, urban planning and sanitation. 


\section{Box 1. Organisation of primary and secondary education in Sweden}

Compulsory education consists of compulsory pre-school class (förskoleklass) and compulsory school (Grundskola), plus the Sami school and schools for pupils with certain disabilities. It is provided in one single structure covering children aged 6 to 16, corresponding to primary school and lower secondary school (ISCED levels 1 and 2). About 1024000 pupils were enrolled in the Swedish compulsory school system in the school year 2016/17. Most pupils attended municipal schools, while 154000 (approximately 15\%) attended private (including international) schools. Around 344000 pupils attended upper secondary school (Gymnasieskola), of which 88000 (approximately 25\%) attended private schools.

The school system has been decentralised since the early 1990s. Municipalities and private school providers are responsible for primary and secondary schools, including organisational development and control, and teacher training and competence development. Municipalities are in addition responsible for adult education. School funding is set at the discretion of each municipality, with the exception of some targeted state grants.

National steering is based on broad direction from the government, who sets goals mainly through the Education Act and the National Curriculum, supported by the National Agency for Education and the School Inspectorate, which also have key roles in monitoring the implementation and fulfilment of these goals. National tests in mathematics and Swedish (including Swedish as a second language) are given in the third, sixth and ninth grade. National tests are also given in English in the sixth and ninth grades, and in one of the subjects biology, physics or chemistry as well as one of the subjects geography, history, religion or social sciences in the ninth grade. In upper secondary school the national tests cover mathematics, Swedish and English.

Compulsory school pupils are entitled to a place in a municipal school based on proximity, but may choose another municipal school (usually within the municipality) or private school (regardless of location), subject to capacity. Private providers have their own admission systems, which need to be non-discriminatory. The usual admission criteria are siblings already admitted, geographical proximity and the time of application (first-come-first-served). Upper secondary admission is based on compulsory school grades, and not limited by municipal borders.

Rules guiding private schools are designed to create a level playing field between public and private schools. Private schools can be freely established following approval by the Swedish Schools Inspectorate that they fulfil the criteria of the Education Act. They follow the same rules as public schools, and teach the same curriculum (except for international schools), and they are subject to the same inspection regime as municipal schools.

Municipalities are obliged to finance compulsory and upper secondary education of resident children, including children attending a private school or a school run by a different municipality. Funding of resident children attending schools other than those run by the municipality is based on the actual cost of provision or the cost of organising the same programme in public schools in the home municipality. Schools (private and public) are not allowed to charge tuition fees.

Source: Skolverket (2017[9] $)$; OECD (2015 $[10])$ and André, Pareliussen and Hwang (2019[7]). 
Decentralisation allows more proximity with users, but it also entails challenges to equality of access and quality of services across the country and recruitment of qualified staff, notably education and health personnel.

Higher local needs and/or a thinner revenue base caused by for example demographics, internal- and external migration patterns, and differences in strength and structure of local labour markets are met by a national income-and-cost equalisation system designed to allow an equal provision of services across the country.

Perhaps a bigger challenge than financing is to attract and retain qualified staff. Shortages of qualified personnel, in particular nurses and teachers, are constraining health care and education services (Figure 2) (SKL, 2018 ${ }_{[11]}$ ), notably in remote locations, as the young and educated tend to move to cities, notably the main agglomerations Stockholm, Gothenburg and Malmö (Mellander and Bjerke, 2017 $[12]$ ).

Figure 2. Sweden faces teacher shortages, notably in rural areas

A. Index of shortage of educational staff

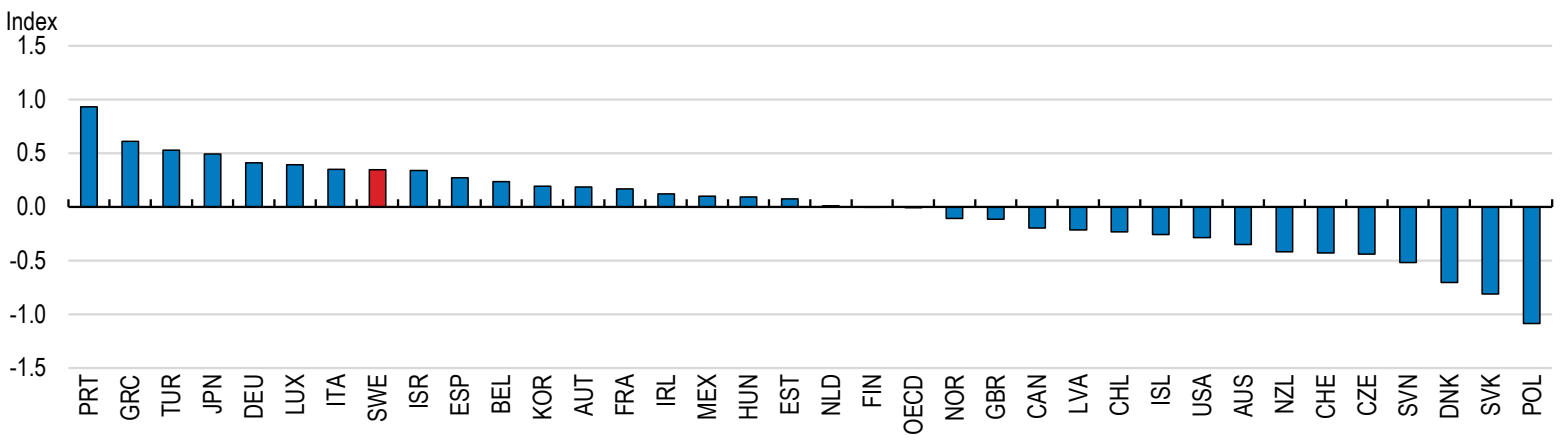

B. Shortage of educational staff, difference between cities and rural areas

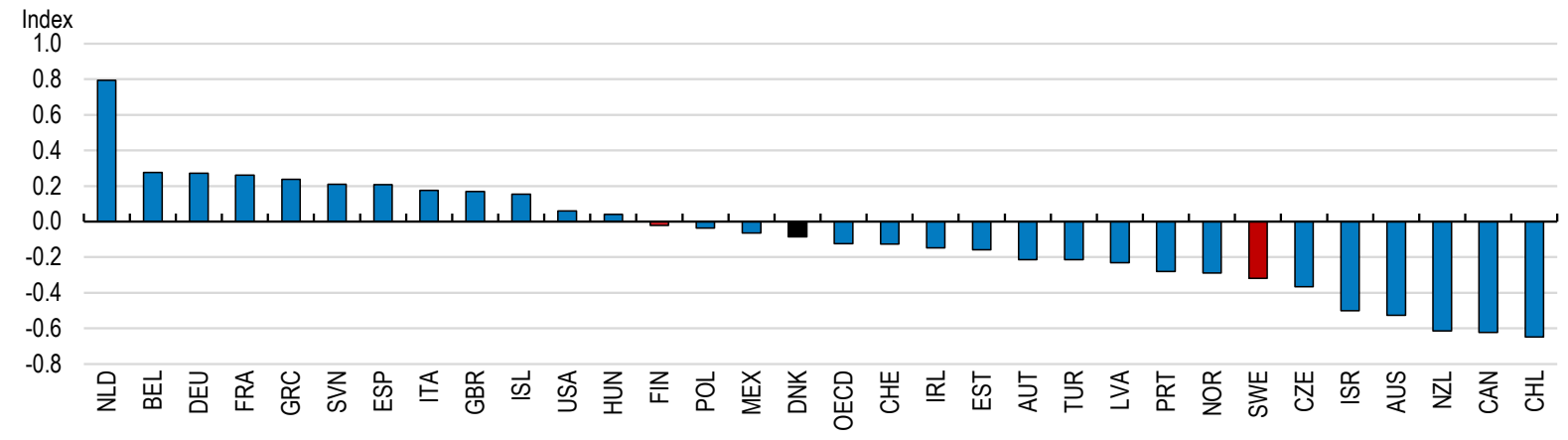

Note: Positive values indicate higher shortages, as reported by school principals. Panel B is calculated as shortages in cities minus shortages in rural areas. Negative values hence indicate higher shortages in schools in rural areas.

Source: OECD, PISA 2015 Database, Table II.6.15.

StatLink त्गाजम https://doi.org/10.1787/888933944234

The current teacher shortages are set to intensify going forward, mainly due to a rapid increase of pupils at all educational levels. Nearly $40 \%$ of teachers are aged 50 or over and $14 \% 60$ or over (Figure 3, Panel A). These shares are among the highest in the OECD, being surpassed only in the Baltic states and some Central European countries. The proportion of older teachers is highest in upper secondary education, where many 
vocational teachers are recruited from outside professions, followed by post-secondary and tertiary education. The age structure at lower levels of education is somewhat more favourable (Panel B). Recruiting enough new teachers is proving difficult, despite recent government efforts to make the profession more attractive, both in terms of pay and career paths.

Figure 3. A sizeable share of Sweden's teachers are over fifty

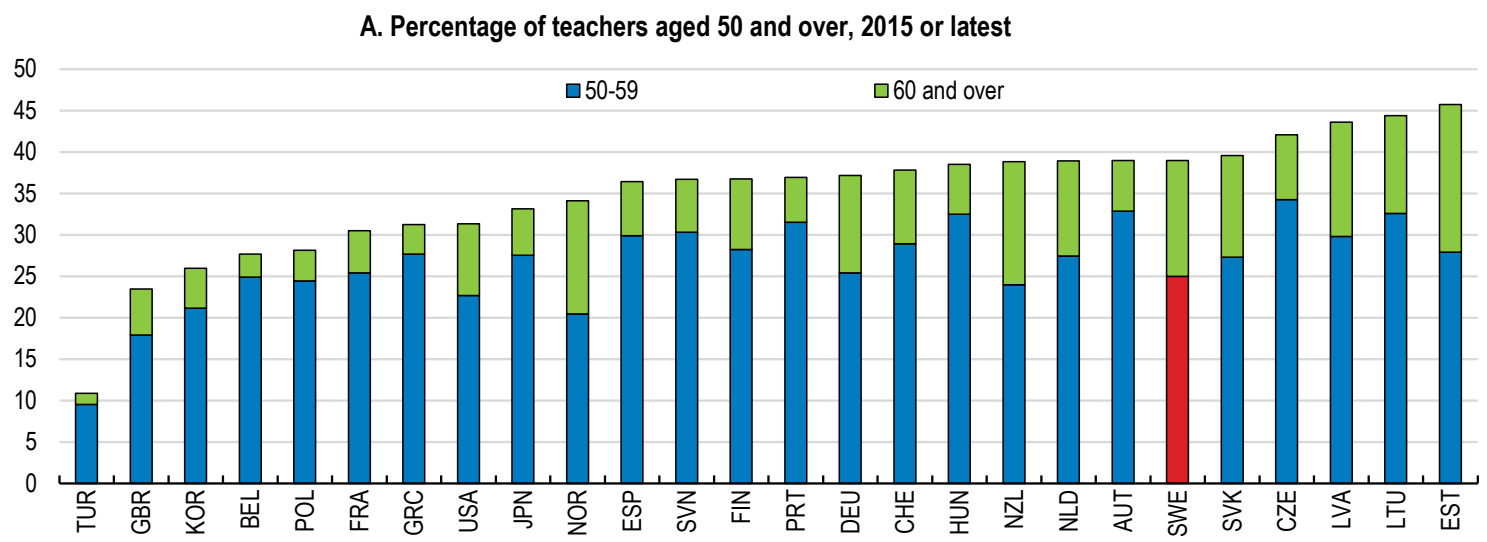

B. Percentage of Swedish teachers aged 50 and over by education level, 2015

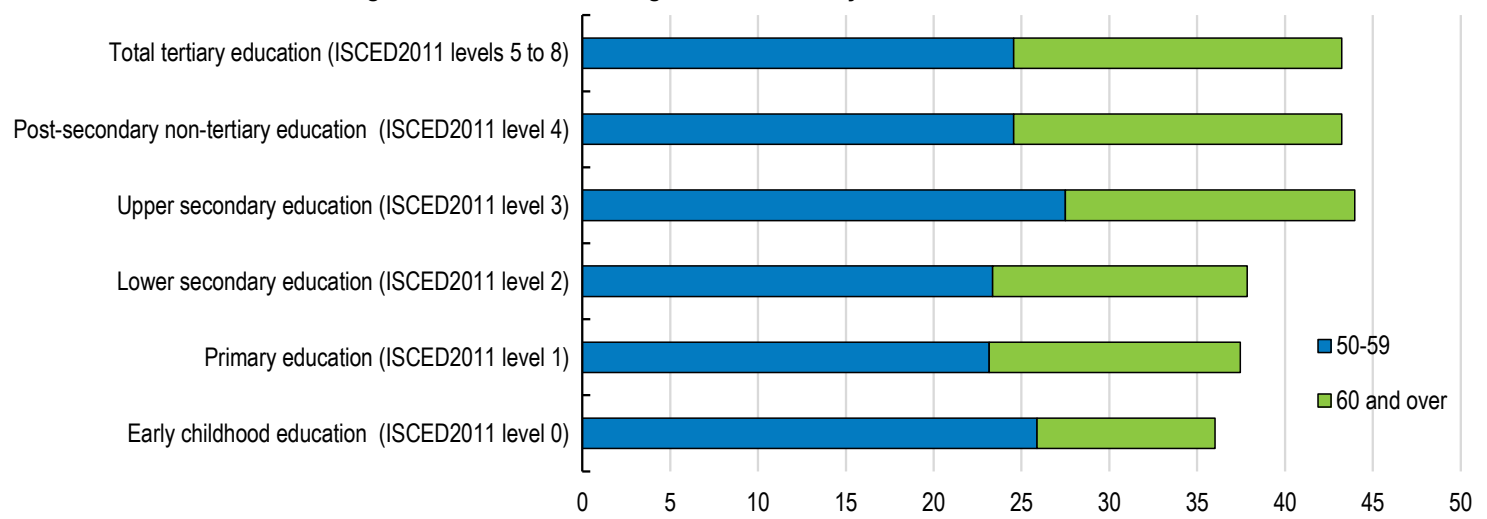

Source: OECD, Education at a Glance.

StatLink *inाs https://doi.org/10.1787/888933944253

\section{Declining quality and equity in schools challenge Sweden's growth model}

Sliding and more unequally distributed skills affect individuals, as people in Sweden need both a formal education and basic skills, such as literacy and numeracy, to get a job and keep it (Bussi and Pareliussen, 2017 ${ }_{[13]}$ ). More broadly, this trend challenges Sweden's societal model, built around high skills. Sweden specialises in high value-added parts of global value chains, demanding high skills to succeed in tough global competition. Coordinated wage-setting compresses wages, notably by raising them in the bottom of the distribution, which makes it challenging for individuals with low skills and productivity to find employment (Swedish Labour Policy Council, 2016 $6_{[14]}$ ). More unevenly distributed skills are thus likely to lead to increasing social exclusion. Adding to the challenge, high humanitarian and family reunion immigration increases the share of low skilled-workers (OECD, 2017 [5]; OECD, 2015 [15]; Pareliussen et al., 2018 $\left.8_{[16]}\right)$. 
Despite the Swedish school system's strengths, such as in fostering civic engagement, cooperation, foreign language skills, pupil satisfaction and learning to learn, pupils do not catch up from low PISA results after the age of 15. Those cohorts which scored low in PISA had correspondingly weak results as adults (OECD, 2015 $\left.{ }_{[15]}\right)$ (Figure 4). Countries scoring below average in PISA do not generally catch up in the PIAAC survey. A number of countries have had above-average results in PISA, but below average in PIAAC, but none has scored below average in PISA and significantly above average in PIAAC.

Figure 4. Young adults do not catch up from low PISA scores

Average Swedish PISA and PIAAC scores for corresponding age cohorts

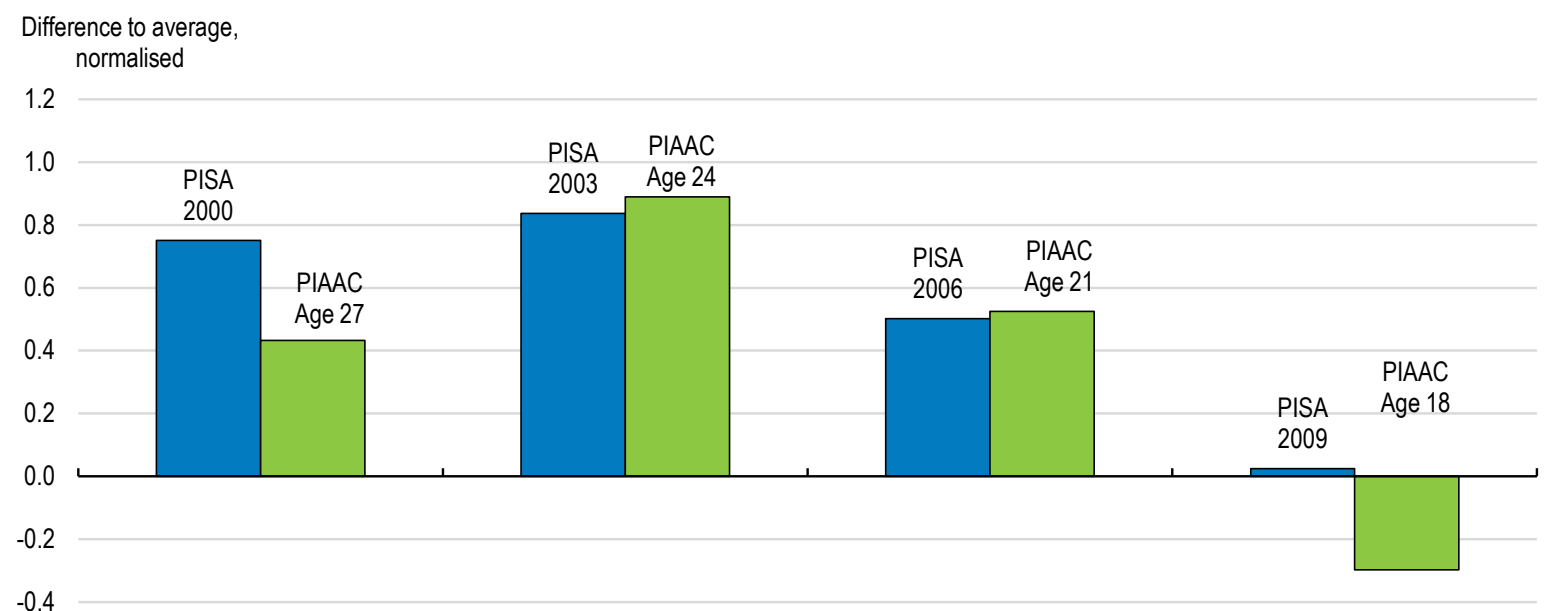

Note: The figure compares mean reading scores in PISA with literacy scores in PIAAC for the corresponding cohorts. The test score averages are normalised by the cross-country PISA and PIAAC averages and standard deviations for comparison. A three-year band is used in the Survey of Adult Skills to increase size and reliability of estimates, i.e. the group "adults 24" consists of the age groups from 23 to 25 . The mix of countries contributing to the average in PISA and the Survey of Adult Skills differs, which may contribute to differences in countries' average scores relative to the overall averages in either study.

Source: Survey of Adult Skills (2012); OECD, PISA 2009 Database; and OECD, PISA 2012 Database.

StatLink त्ञाज https://doi.org/10.1787/888933944272

Swedish children have a long-standing legal right to a school system supporting high and equitably distributed skills, set out in the main overarching goals of primary and secondary education in the 1985 and 2010 Swedish Education Acts. The quality goal states that pupils should develop knowledge, but also values, such as respect for human rights and democratic values central to Swedish society. The equity goal states that that schools shall adapt to pupils' different needs and strive to counterbalance differences in pupils' backgrounds (and geographical location) so that they can reach their full potential. (Sveriges Riksdag, 2010 ${ }_{[17]}$; Sveriges Riksdag, 1985 $5_{[18]}$ ).

\section{Results have fallen in primary and secondary education}

A large body of research, including the OECD Programme for International Student Assessment (PISA), has documented that the Swedish school system's ability to fulfil these goals has eroded since the 1990s. Sweden was one of the top PISA performers in the first PISA survey in year 2000, after which the performance of 15-year-olds deteriorated more rapidly than in any of the other participating countries until 2012. Results fell in reading, mathematics and science, and other international tests confirmed the weakening. The latest 
measurements indicate that results may have bottomed out, with improvements in PISA 2015, the Trends in International Mathematics and Science Study (TIMSS) 2016 and the Progress in International Reading Literacy Study (PIRLS) 2015 (Figure 5) (Gustafsson, Sörlin and Vlachos, 2016 ${ }_{[2]}$; School Commission, 2017[3]; OECD, 2016 $\left.{ }_{[4]}\right)$.

Figure 5. A rapid decline in school results may have bottomed out

Sweden's test results in international skills surveys for children of school age

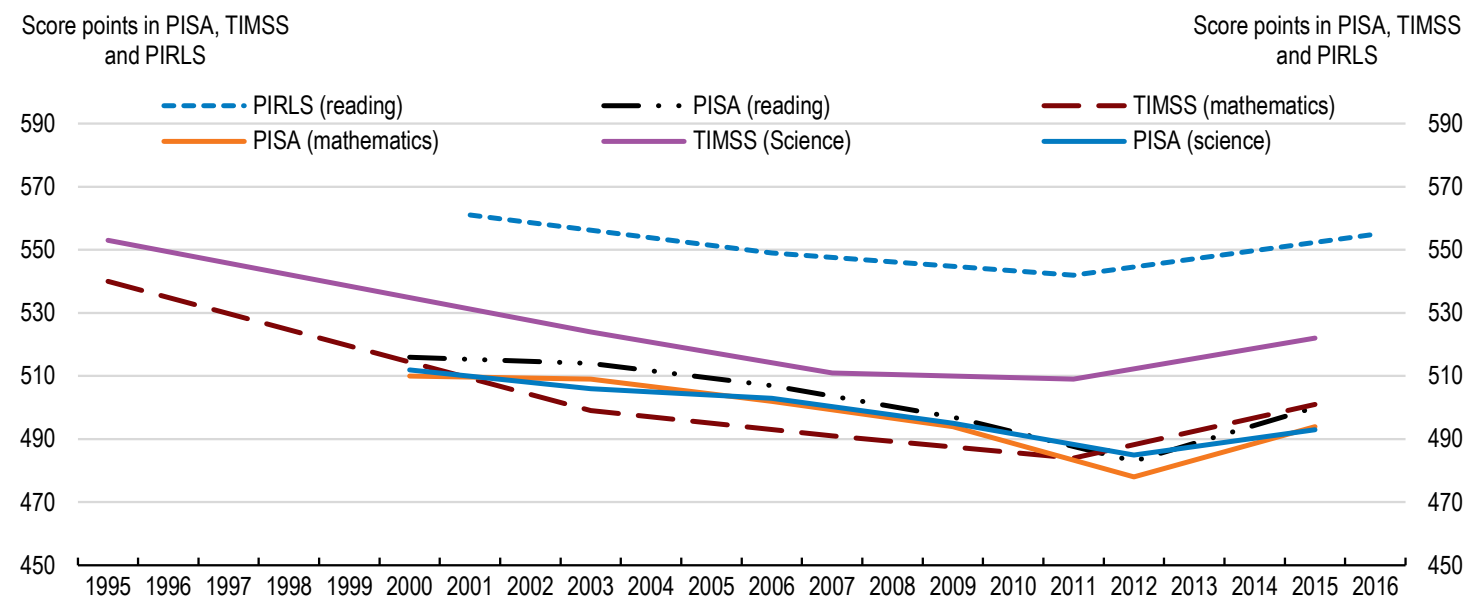

Note: PIRLS denotes the national average results of fourth-graders in the Progress in International Reading Literacy Study. TIMSS denotes the national average results of eight-graders in the Trends in International Mathematics and Science Study. PISA denotes the national average results of 15 -year-olds in the OECD Programme for International Student Assessment.

Source: OECD (2016[4]), Mullis et al. (2017[19]; 2016[20]), and Martin et al. (2016[21]).

StatLink त्ताst https://doi.org/10.1787/888933944291

\section{Pupils'performance depends on who their parents are}

The gap between the highest- and lowest-performing pupils is widening, and socioeconomic factors, such as immigrant origin and parent background, increasingly affect grades. This polarisation accelerated since the end of the 2000s. However, increased polarisation is at least partially a result of foreign-born children entering Swedish schools at a higher age and with a weaker educational background. Pupil's socio-economic backgrounds explained $12 \%$ of the total variation in science performance in the 2015 PISA survey. This is almost at the OECD average, and significantly higher than in any of the other Nordics, where socio-economic backgrounds explain between 5\% (Iceland) and 10\% (Denmark) of the total variation (OECD, 2016 ${ }_{[4]}$; Skolverket, 2018 $8_{[6]}$; Heller Sahlgren, $\left.2017_{[19]}\right)$. Result differences between schools almost doubled from 2000 to 2016, widening particularly fast since the end of the $2000 \mathrm{~s}$. $65 \%$ of between-school variation in science performance in Sweden was explained by socio-economic backgrounds in the 2015 PISA survey. This is above the OECD average of $63 \%$, and considerably higher than in the other Nordics, where socio-economic backgrounds explain between 34\% (Norway) and 51\% (Denmark) of the variation (OECD, 2016 $\left.{ }_{[4]}\right]$.

Increasing school segregation, where pupils with similar socio-economic backgrounds tend to cluster in the same schools, can explain most of the divergence (Figure 6). School segregation is driven by neighbourhood segregation and school choice, a choice mainly exercised by pupils with favourable socio-economic backgrounds. School segregation affects individual pupils' results when there are peer effects. Increasing segregation may 
benefit well-endowed pupils since pupils with well-educated, Swedish-born and highearning parents typically perform well in school, and these pupils may gain further from going to class with other high-performers with similar backgrounds. Sund $\left(2009_{[20]}\right)$ finds that such peer effects are stronger for Swedish pupils with unfavourable socio-economic backgrounds, and that these pupils thus lose more from segregation than pupils with favourable backgrounds gain (Figure 7). Therefore, despite the lack of undisputable evidence of peer effects, school segregation risk depriving pupils of equal opportunities to achieve their potential and may even lower average school outcomes in Sweden (Skolverket, 2018 [6]; Böhlmark, Holmlund and Lindahl, 2016 [21]; André, Pareliussen and Hwang, 2019[7]; Yang Hansen and Gustafsson, 2016 $6_{[22]}$. In response to this challenge, the Government initiated a public enquiry in 2018 to analyse increasing school segregation and propose policies to reduce it and foster equal opportunities within the compulsory school system.

\section{Figure 6. School segregation leads to diverging school results}

Between-school grade variation controlling for socio-economic background

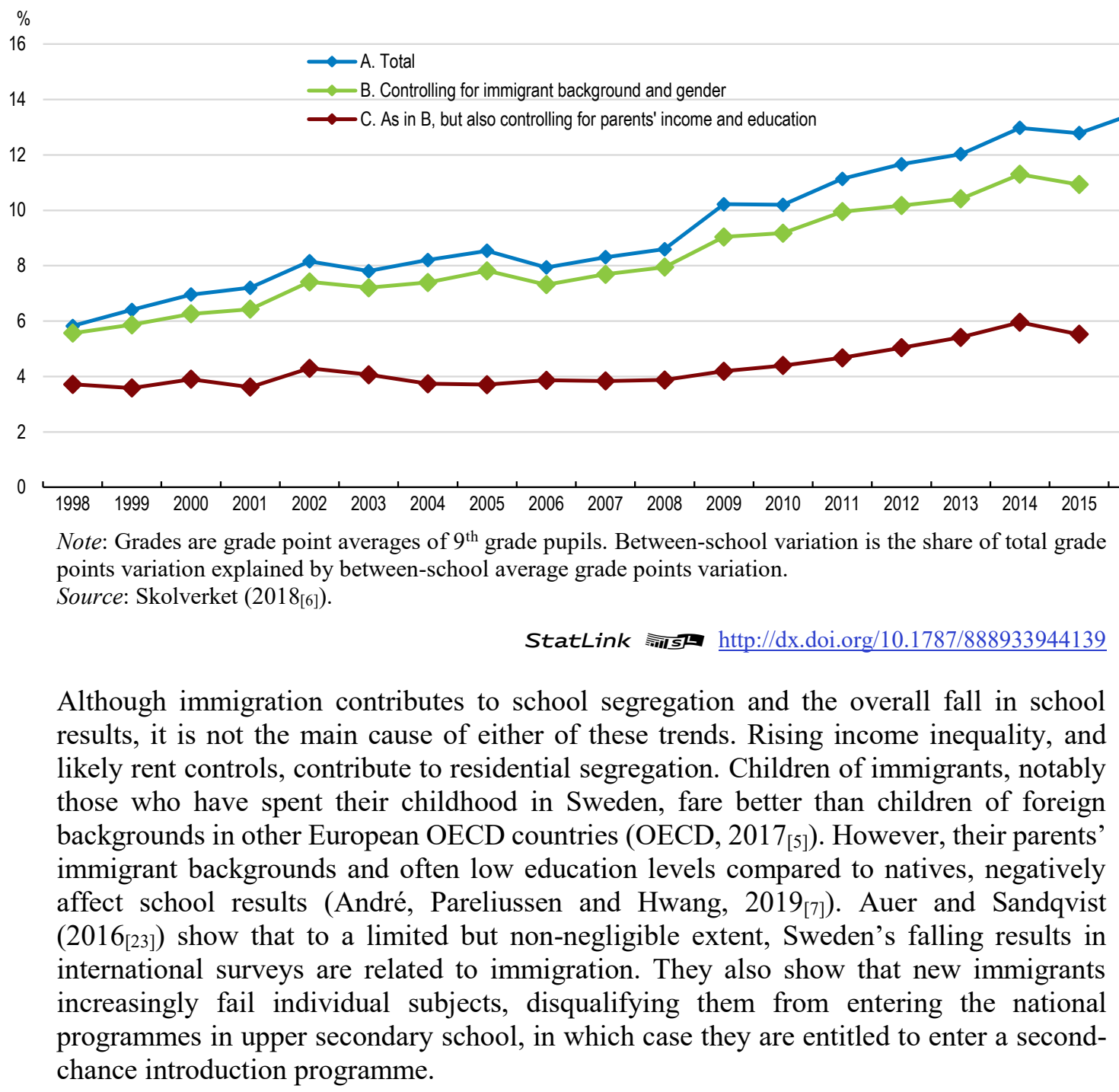




\section{Figure 7. Peer effects are stronger for children with weaker socio-economic backgrounds}

Result difference between pupils attending the top and bottom performance quartiles of schools, by pupil socio-economic background index value

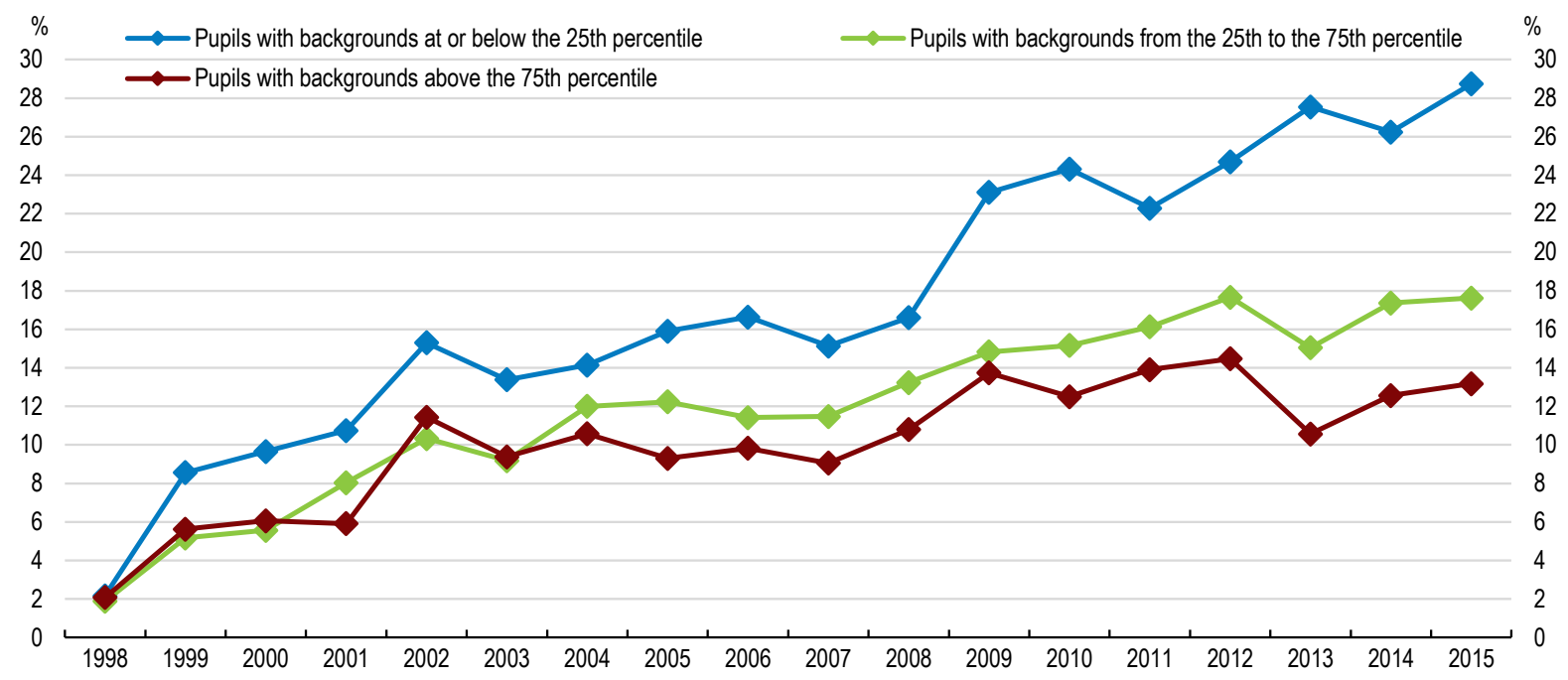

Note: Results are total grade points of $9^{\text {th }}$ grade pupils. The socio-economic background index is notably based on parent income and education, immigrant background and gender. Note that increasing peer effects are partly a result of an increasing polarisation of the pupil mass, notably a higher share and less favourable composition of pupils with immigrant background.

How to read this figure: The figure shows the difference in grades between pupils attending the best performing schools and the worst performing schools, by pupils' ranking on the socio-economic index. For example: a pupil in the lowest socio-economic quartile (blue line) attending a school in the top result quartile achieved approximately $29 \%$ higher grades than a pupil with a similar background attending a school in the bottom result quartile in 2015.

Source: Skolverket (2018[6]).

StatLink तiाs https://doi.org/10.1787/888933944310

School segregation is mainly a city phenomenon, because there is limited practical scope for school choice and neighbourhood segregation in more sparsely populated areas, and immigrants tend to settle in the cities. Both high-performing and low-performing schools are overrepresented in greater Stockholm and greater Malmö compared to the rest of the country, while school performance is more evenly distributed in greater Gothenburg (André, Pareliussen and Hwang, 2019 $\left[{ }_{[7]}\right.$ ) (Figure 8).

Average school results also differ between regions, with schools in the Greater Stockholm functional labour market area achieving the highest results, followed by Malmö and Gothenburg. These geographical differences are not sensitive to differences in inputs such as expenditure per pupil and the share of certified teachers. On the other hand, they tightly correspond to pupils' different socio-economic backgrounds, notably that a higher share of parents in the cities have higher education, one of the strongest explanatory factors behind school results. Controlling for socio-economic backgrounds, school inputs and a range of additional controls, schools in the Stockholm, Malmö and Gothenburg areas perform slightly better than the country average (Figure 9) (André, Pareliussen and Hwang, 2019 $9_{[7]}$ ). 
Figure 8. School results are more polarised in Stockholm and Malmö

School average national test scores in mathematics by region (2017)

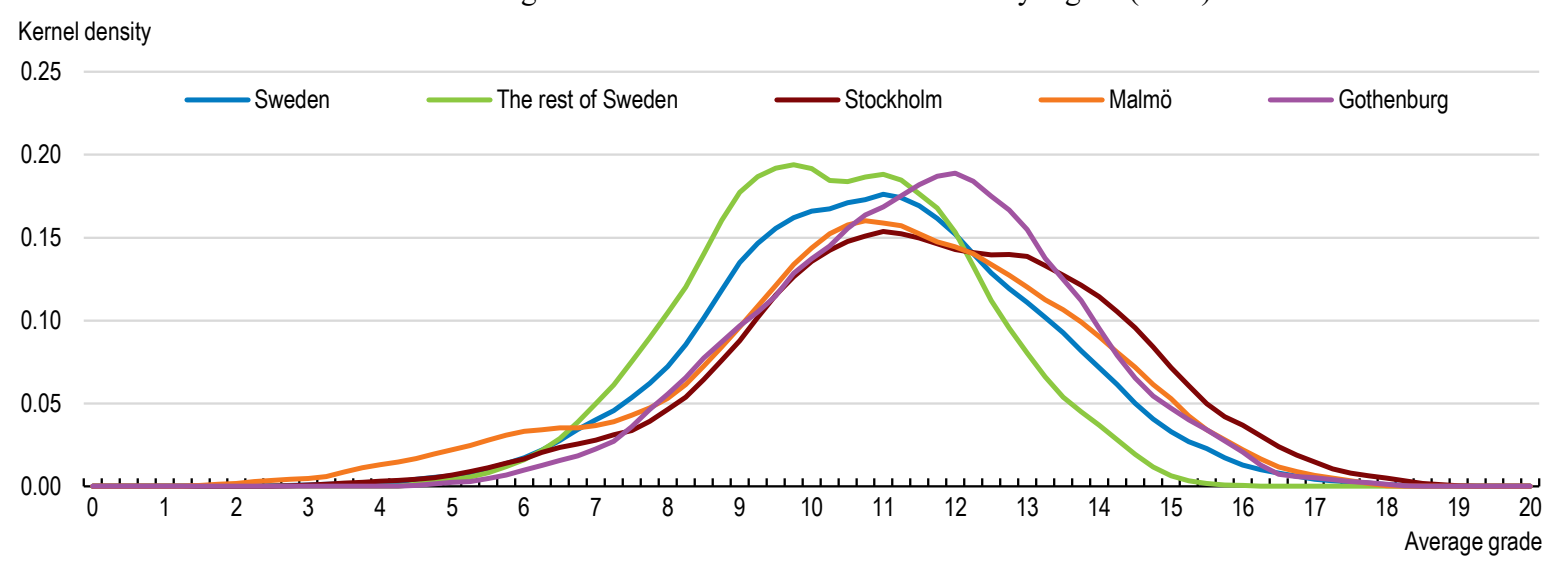

Note: The Kernel density is estimated using the Epanechnikov function. The three cities are defined as functional labour market regions (Statistics Sweden, 2018[24]).

Source: Authors' calculations with data from André, Pareliussen and Hwang (2019[7]).

\section{StatLink त्ञाजी https://doi.org/10.1787/888933944329}

Figure 9. Geographical result differences largely reflect socio-economic backgrounds

Difference in test scores compared to the rest of Sweden

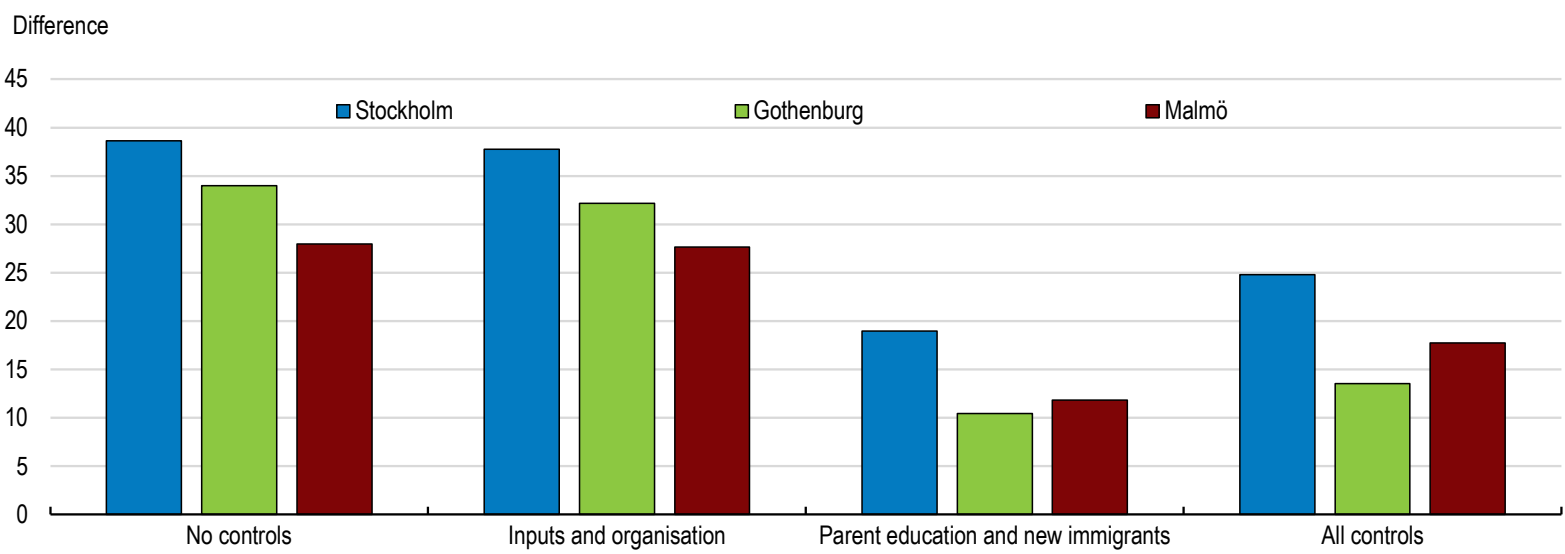

Note: The differences to test scores in the rest of Sweden are dummy regression coefficients for schools within the three major agglomerations, defined as functional labour market regions (Statistics Sweden, 2018 [24]) from a random-effects panel regression on the logarithm of national test scores in mathematics with data covering 2013-17. "All controls" corresponds to the main specification in André, Pareliussen and Hwang (2019[7]). "Parent education and new immigrants" controls for the education level of parents and the share of pupils having immigrated during the four years preceding the test. "Inputs and organisation" controls for the average municipal expenditure per pupil, the share of certified teachers, the number of pupils per teacher and a survey measure of adaptation of education to pupils' needs.

Source: Authors' calculations based on André, Pareliussen and Hwang (2019[7]).

StatLink त्राज़ https://doi.org/10.1787/888933944348

\section{Reasons for falling performance are complex, but likely linked to 1990s reforms}

Swedish schools entered the 1990s from a position of strength, as one of the top performers in early international comparative school surveys. A suite of sweeping school reforms in the early 1990s promoting decentralisation, management by objectives, school choice and competition likely weakened school performance over time, even though results may have 
peaked before the reforms (Gustafsson, Sörlin and Vlachos, 2016 ${ }_{[2]}$; School Commission, 2017 $[3]$; Holmlund et al., 2014 $\left.4_{[25]}\right)$. Weakened results likely reflects concrete issues of design and implementation, rather than the general direction of reform, as several successful school systems in the OECD are decentralised and contains elements of choice, management by objectives and private provision (OECD, 2017 $[26])$.

Quantitative evidence of the impact of the reforms on school performance is lacking because of data limitations and the nature of the reforms. The reforms were implemented at the same time over the whole country, so there is no control group. Furthermore, school reforms will affect results only gradually. Teaching staff remain in their positions, and changes to formal organisation will therefore not turn into changed practices overnight. New teacher qualification requirements will only slowly affect the stock of teachers. In addition, the results of pupils close to graduation depend mostly on the old system. Measuring outcomes is also difficult. Grades cannot be used as an objective benchmark. The grading system has changed over time, and grade inflation as well as differences in grading standards across schools are well-documented, but difficult to correct for (Vlachos, $\left.2018_{[27]}\right)$. More robust skills measures from international surveys are only available from 1995. Adding to the challenge, reforms have been implemented in a changing society, such as the digital revolution profoundly changing reading habits, also affecting school outcomes in ways not fully understood. Against this complex background, it is clear that quantitative research, although informative (Box 2), can only give partial answers, and needs to be understood in a wider, qualitative context.

The timing of falling results points to a role for the 1990s reforms. According to Gustafsson, Sörlin and Vlachos $\left(2016_{[2]}\right)$, reading skills of compulsory school graduates peaked in the early- to mid- 1990 s, while mathematics skills started falling in the early 2000 s. Since education reforms will only affect results with a lag, this timing points to the 1990 s reforms as a likely main culprit (Figure 10). Holmlund et al. $\left(2014_{[25]}\right)$ argue that the decline started earlier, but accelerated after the reforms. Furthermore, key institutional weaknesses are directly linked to these reforms, which are an important point of departure to analyse the current systemic weaknesses of the Swedish school system (OECD, 2015 ${ }_{[15]}$; OECD, $\left.2015_{[10]}\right)$.

Figure 10. Adult skills are highest among cohorts graduating from compulsory school around the time of the $1990 \mathrm{~s}$ reforms

Difference to PIAAC average by 10 -year age cohort

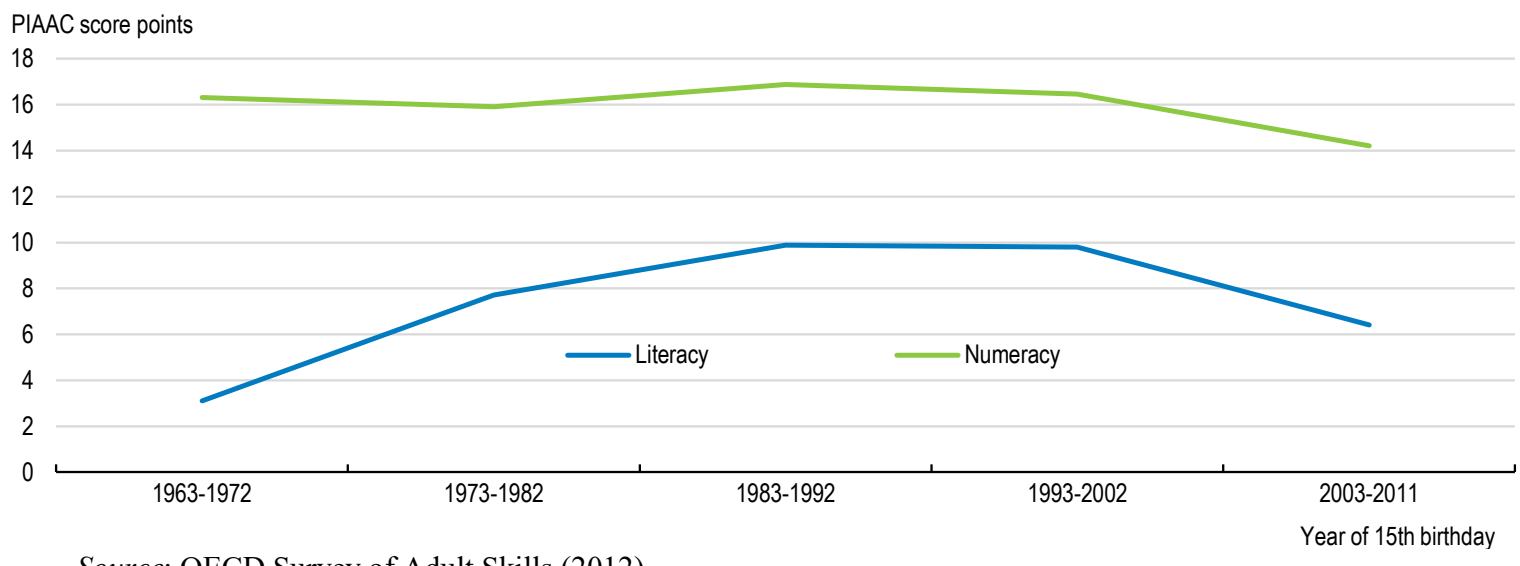

Source: OECD Survey of Adult Skills (2012). 


\section{Box 2. Drivers of school performance in a panel regression set-up}

André, Pareliussen and Hwang $\left(2019_{[7]}\right)$ use a panel dataset of Swedish lower secondary schools with data covering the years 2013-17 to identify the main drivers of school performance, measured by school-average scores in national math tests in the $9^{\text {th }}$ grade, which is the final year of compulsory school. The model estimates a production function of educational outcomes using various panel regression methods, with fixed and random effects, as well as panel stochastic frontier analysis, which sheds light on the level and distribution of school inefficiencies.

Socio-economic backgrounds, notably parent education, is the factor most closely associated with results, but school inputs, such as organisational quality, measured through a survey variable of the adaptation to pupil needs, also matter, as do the share of qualified teachers and the type of school provider. The intensity of local competition has a negative coefficient, insignificant for the full sample but significant for schools in the lower part of the socio-economic distribution (Figure 11).

Figure 11. Drivers of school performance in Sweden

Change in mathematics test score associated with a one standard deviation change in the independent variables

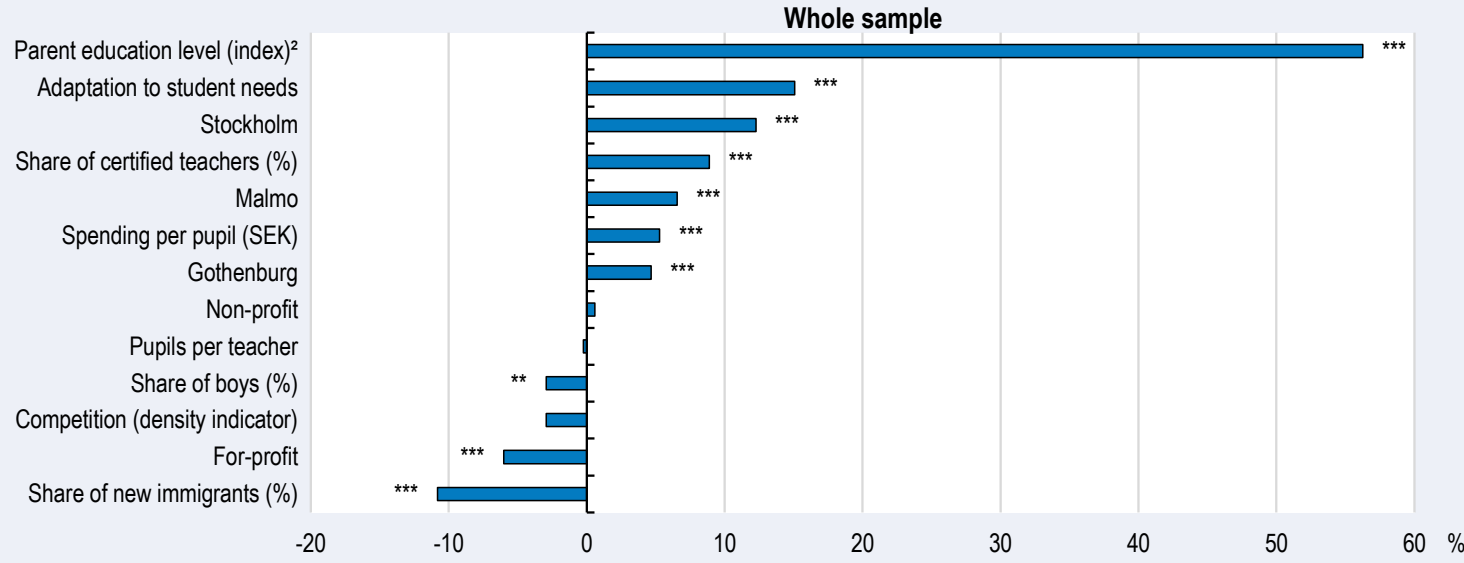

Note: Regression results from the main specification in André, Pareliussen and Hwang (2019[7]), expressed in percentage of the standard deviation in the natural logarithm of test scores. ${ }^{*}, *$ and $* * *$ denotes significance at the $90 \%, 95 \%$ and $99 \%$ level, respectively.

Source: André, Pareliussen and Hwang (2019[7]).

StatLink הत्गाजמ https://doi.org/10.1787/888933944386

These results should be interpreted with caution, as they represent correlations around the average of each variable. For example, for-profit schools have weaker performance than municipal schools on average, given the same inputs and pupil mix, but there are also highly performing for-profit schools, and inputs differ between the different school types. Endogeneity is also an issue, notably for spending per pupil and the share of certified teachers. 


\section{Decentralisation and competition reforms rested on shaky foundations}

The original decentralisation reform of 1991 left municipalities with the full responsibility for schools and adult education, organisational development and control, and teacher training and competence development. It was followed by the abolition of earmarked grants in 1993, leaving municipalities with the discretion to prioritise between schools and other municipal tasks (OECD, 2015 $[15])$.

Two school choice reforms were implemented in 1992, allowing public grants to private independent schools and giving pupils the possibility to choose between private and public schools. Rules for teacher qualification assessments were abolished in 1993, and a new curriculum with relatively broad learning objectives and a new grading system were both implemented in 1994 (OECD, 2015 $5_{[15]}$ ). Existing governance structures, including the National Education Board and Regional Education Boards were abolished and replaced by the National Agency for Education, which had a narrower mandate to evaluate school performance, notably based on subject grades, and with unclear means to address shortcomings (OECD, 1992[28]).

The reforms reflected beliefs in the potential for competition and local rule to boost innovation and diversity and thus improve quality and make schools more cost-effective. Competition and local discretion were thought to enable and nudge schools and teachers to adapt to the individual needs of pupils. Furthermore, it was thought that schools would be better adapted to their local context when school staff were given increased discretion and that communication with and the influence of parents and other local stakeholders would improve with school choice, competition and locally anchored decisions. The reforms were also affected by the needs to reduce public spending in the aftermath of the early 1990s financial crisis $\left(\mathrm{OECD}, 2015_{[10]}\right)$.

In hindsight, the case for fundamental reform was weak, and some of the main challenges of the ambitious reform programme were ignored, despite being raised by stakeholders at the time. The 1992 OECD education review of Sweden pointed out that the reforms would weaken management structures and introduce unclear objectives, an obvious weakness in a system of management by objectives. The review further pointed out that even though Swedish school performance was portrayed as being in decline in the public debate, there was no clear evidence of weaknesses in the existing system and no concrete analyses indicating how the reforms would help (OECD, 2015 ${ }_{[15]}$; OECD, 1992 $\left.{ }_{[28]}\right)$.

Well-performing school systems in many countries contain elements similar to Sweden's, and the general direction of the 1990s reforms was not bound to lead to falling learning outcomes. For example, Finland, a high performer in international rankings, has a highly decentralised system, but a strong teacher profession maintains high education quality, and the government promotes educational equity with a central grant covering around half of compulsory school funding $\left(\mathrm{OECD}, 2015_{[15]}\right)$. Denmark has a decentralised school system, with a substantial and growing share of private schools, but socio-economic conditions of school-age children are taken explicitly into account in municipal funding, and publicly funded private schools are run by the non-profit sector. The Netherlands, another strong performer, also has a decentralised system with school choice and liberal establishment of private providers, but coordinate and provide funding directly from the central level to schools, and only non-profit providers receive public funding (Box 3). Charter schools in the United States also have strong similarities to the Swedish system, as explained below.

The Swedish reforms succeeded on some accounts. Pupils and parents saw their influence increase through more dialogue with local representatives, teachers and headmasters. 
Swedish pupils continue to perform well along dimensions not measured by PISA, such as civic attitudes and foreign languages. However, the sum of reforms fundamentally broke with long-established, well-functioning organisational structures and philosophies of schooling, replaced the curriculum and reformed teacher education and qualifications without making sure that the new system was capable of delivering good results, or even that it was internally consistent (OECD, 2015 [15]; OECD, 1992 $\left.{ }_{[28]}\right)$.

Decentralisation and the transition to a hands-off approach to management were abrupt and went further than originally planned. Both the centrally articulated objectives and the new curriculum were too vague, with too much emphasis on pupils' responsibility for their own learning. The different stakeholders lacked a clear understanding of their tasks and responsibilities following the implementation of the reform, and teachers, who were against the reform from the beginning, showed little enthusiasm for implementation. The division of responsibilities is still not clear between the state, municipalities, headmasters and teachers, and resources and responsibilities are often poorly aligned (OECD, 2015 $5_{[15]}$; OECD, 2015 [10]).

Fundamentally, the old system where schools were all organised within the public service and presumably had maximising the public good in line with the Education Act as their main goal put lower demands on governance and control than the new system. A liberal establishment regime, competition for pupils and allowing for private profits introduces a new set of incentives that requires stronger governance and control. Instead, governance structures were weakened, notably by closing the regional education boards (Gustafsson, Sörlin and Vlachos, 2016 $[2])$.

Many activities benefit from a broader perspective than the municipal one. Without central steering and funding, some important aspects of policy inputs, such as teacher wages, compensatory funding of socio-economic needs and continuous learning activities for teachers drifted in the wrong direction. Indeed, many municipalities still lack the organisational capacity to run schools effectively (OECD, 2015 [15]). Also, the voucher system stymies cooperation between schools who see themselves as competitors for the same funding (Dahlstedt and Fejes, 2018 ${ }_{[29]}$ ).

Decentralisation coincided with the 1990 s economic crisis. Savings triggered by the crisis and the reform were in many cases the wrong ones, and over time they undermined quality. Declining resources led to more pupils per teacher, less teacher training and teacher salaries losing ground. At the same time, core working hours rose. Administrative complexity increased due to the school choice reforms. Teachers' working conditions deteriorated further with extensive documentation and other administrative requirements, as the state and municipalities intensified reporting, documentation and control measures when the falling results became obvious. Headmasters were also left with more administrative tasks and less time for pedagogical leadership. Over time the attractiveness of the teacher profession declined and teacher education lost popularity. Declining teacher skills and an increasing share of teaching staff without adequate qualifications followed (OECD, $\left.2015_{[15]}\right)$.

\section{Reforms to take back control helped, but also created new issues}

Towards the end of the 2000s it became clear that school results were falling, and the then conservative government responded by tightening control. New policies included more national tests, also for younger age groups, a more detailed curriculum, a new and more detailed Education Act, and a strengthening of the school inspectorate, enabling more frequent and thorough inspections (Persson, 2013 $\left.{ }_{[30]}\right)$. 
More detailed rules and a more stringent inspection regime is an inevitable response to weak results in a highly decentralised system based on competition for funding following pupils. This is because the system to an extent encourages behaviour contrary to the public interest, such as lenient grading to attract pupils, or reducing costs at the expense of educational quality, as discussed later in this paper (Gustafsson, Sörlin and Vlachos, 2016[2]; Böhlmark, Holmlund and Lindahl, 2016[21]). However, such a system encourages a culture of compliance with minimum legal requirements in cases where providers' interests conflict with public interests. It increases the administrative burden and may stifle innovation and teacher autonomy at the local level (OECD, 2015 $\left.5_{[10]}\right)$.

The centre-left government taking office in 2014 introduced targeted grants to respond to some distinct problems. These grants were notably meant to benefit pupils from weak socio-economic backgrounds, and to raise the attractiveness of the teacher profession. A more active central government role in school funding is warranted, but a system where municipalities provide schools with their core funding while a multitude of goals have their own targeted grants, is fragmented and sub-optimal. In practice, many of these grants have benefitted schools and municipalities with sufficient administrative resources to apply for and obtain them rather than schools and municipalities who need them most (Gustafsson, Sörlin and Vlachos, 2016[2]; School Commission, 2017[3]).

Parties across the political spectrum have agreed on the need to strengthen teaching in reading, mathematics and science. The number of teaching hours in mathematics has increased progressively from 2013 onwards, and the reading-writing-mathematics guarantee coming into force in 2019 introduces mandatory evaluations of pupils' reading, writing and mathematics skills from an early age, followed by extra support for those who need it. A number of targeted grants support these efforts (Ministry of Education and Research, 2016 $[31]$ ).

\section{A reform consensus is taking shape, but some issues remain contentious}

The political right's approach of strengthening the control regime, the political left's approach with targeted grants, and the cross-party approach towards strengthening basic skills may all improve results, and have likely contributed to halting the fall in PISA results. However, the approach is fragmented, the numerous measures do not always rest on solid research foundations, and they do not respond to the more fundamental questions about what kind of school Sweden wants for the future and how to durably improve results and equal opportunities while maintaining current strengths.

A broad national debate about the past and future of Sweden's schools, supported by previous OECD work (OECD, 2015 ${ }_{[10]}$; OECD, 2015 $\left.[15]\right)$, culminated with the School Commission, a public enquiry appointed by the government in 2015. Members of the Commission came from academia, the National Agency for Education, municipalities, pupils' organisations, teachers' and principals' unions, a private school provider and the Confederation of Swedish Enterprise. They interacted with a parliamentary reference group. The Commission delivered its final report in 2017, with thorough analyses and agreement between commission members on a number of important issues (Box 3 ). 


\section{Box 3. Recommendations of the Swedish School Commission}

The Swedish School Commission delivered its final report in 2017, with the following key recommendations:

- Strengthen and consolidate central government funding into a block grant of approximately $6 \%$ of compulsory school funding, designed to compensate for differences in socio-economic backgrounds.

- Strengthen the regional organisation of the school agencies to support systematic quality improvement, cooperation and competence development for teachers and principals at the local level, as well as coordinating planning and dimensioning of upper secondary schools.

- Introduce a national system with a strong research foundation to provide timely support to pupils with special needs.

- Increase the potential pool of new teachers by offering alternative pathways to teaching. Improve teacher education quality by more cooperation between universities and school providers and a strengthened research base. Ensure systematic and research-based development of teachers' competences and skills, strongly linking research and practice and peer-to-peer learning with support from the strengthened regional organisation.

- Introduce a programme for teachers' and principals' professional and career development, with tracks and qualification levels linked to competence development.

- Cut red tape. The central level and school providers should shield teachers and principals from unnecessary administrative tasks, so that they can focus on the core tasks of teaching and organisation and school leadership.

- Reduce noise in the classroom, improve safety and pupil health by clarifying in the curriculum pupils' own responsibility, and through systematic research on effective methods to this end.

- Reduce school segregation by means of better information about school quality, requiring all parents to actively choose schools and lottery as the required intake method for over-subscribed schools. Legally oblige school providers to work towards socially mixed pupil groups.

Source: Samling för skolan - Nationell strategi för kunskap och likvärdighet (Together for schools - National strategy for knowledge and equity) (School Commission, 2017 [3]).

The representation of a broad spectrum of interests in the Commission is a strength, and such commissions play a useful role in creating consensus across political blocs and between social partners and other stakeholders, a hallmark of political decision-making in Sweden and other Nordic countries. Indeed, the Commission agreed on the problem description and the broad thrust of reform proposals. A few of the least controversial Commission proposals are being implemented, and the report constitutes a solid foundation and clear direction for broad political agreement to repair problematic aspects of the system. 
However, some of the Commission proposals are politically charged, and were not unanimously supported by commission members. Notably, individual members dissented on the proposals to assign places at over-subscribed schools by lottery and to introduce a minimum funding requirement based on socio-economic backgrounds at the school level (School Commission, 2017[3]).

The recommendations in this paper are broadly in line with the School Commission reform proposals. However, the school system is complex, and policies to foster well-functioning schools are context specific and only partially understood. The risk of unintended consequences calls for a cautious approach. Reforms should be implemented in ways allowing for quantitative research on their effects, for example with pilots and differentiating the timing of roll-out across the country. Such testing, experimentation and evaluations should be undertaken systematically and used to adjust policy as needed.

\section{A coherent reform programme should address governance, choice and teachers}

The recommendations in this paper rest on three pillars, forming a coherent reform strategy. The first pillar describes how to adjust the institutional set-up, with a strengthened role for the central government by means of a national minimum norm for compensatory school funding or, alternatively, direct compensatory state funding to schools. Furthermore, a regional structure should be developed to foster cooperation, school- and teacherdevelopment, coupled with and enabling accountability throughout the school organisation.

As a second pillar, school choice and competition should be reformed to align with the public good by reducing information asymmetries, increasing the fairness of the grading system, and reforming school choice to reduce segregation. The establishment and expansion of publicly funded private schools need more coordination to safeguard children's equal opportunities.

The third pillar is about making the teaching profession more attractive in order to recruit and retain teachers to face current and future shortages. Better teacher education with a stronger research base and more teaching practice, clearer career paths and more cooperation, feedback and support between colleagues would help. These measures would also improve teacher quality, which has an important effect on learning.

\section{Rebuilding institutions for central coordination}

Decentralisation in the 1990s went far, as the government gave away control over school funding and abolished regional structures for coordination and quality development. To strengthen the institutional set-up of the school system the central government needs to rebuild these policy levers to take back some of the control they gave away in the 1990s.

\section{Steer school funding to champion equal opportunities}

PISA results show that above a threshold of about 50000 purchasing power parity-adjusted US dollars per pupil in primary and lower secondary school, there is no clear relationship between spending and results (OECD, 2016[32]). Sweden spends somewhat more than the OECD average per pupil. High-achieving countries include those with relatively low expenditures, such as Estonia, and those with relatively high expenditure, such as Singapore. Other high achievers, such as Japan, Canada and Finland all spend less per pupil than Sweden (Figure 12). School performance at Sweden's spending level thus depends more on the effective use of existing resources and the qualitative differences between education systems. 
Figure 12. Higher spending on education does not necessarily improve results

Total spending per pupil between the ages of 6 and 15 and PISA science performance Science performance (score
points)

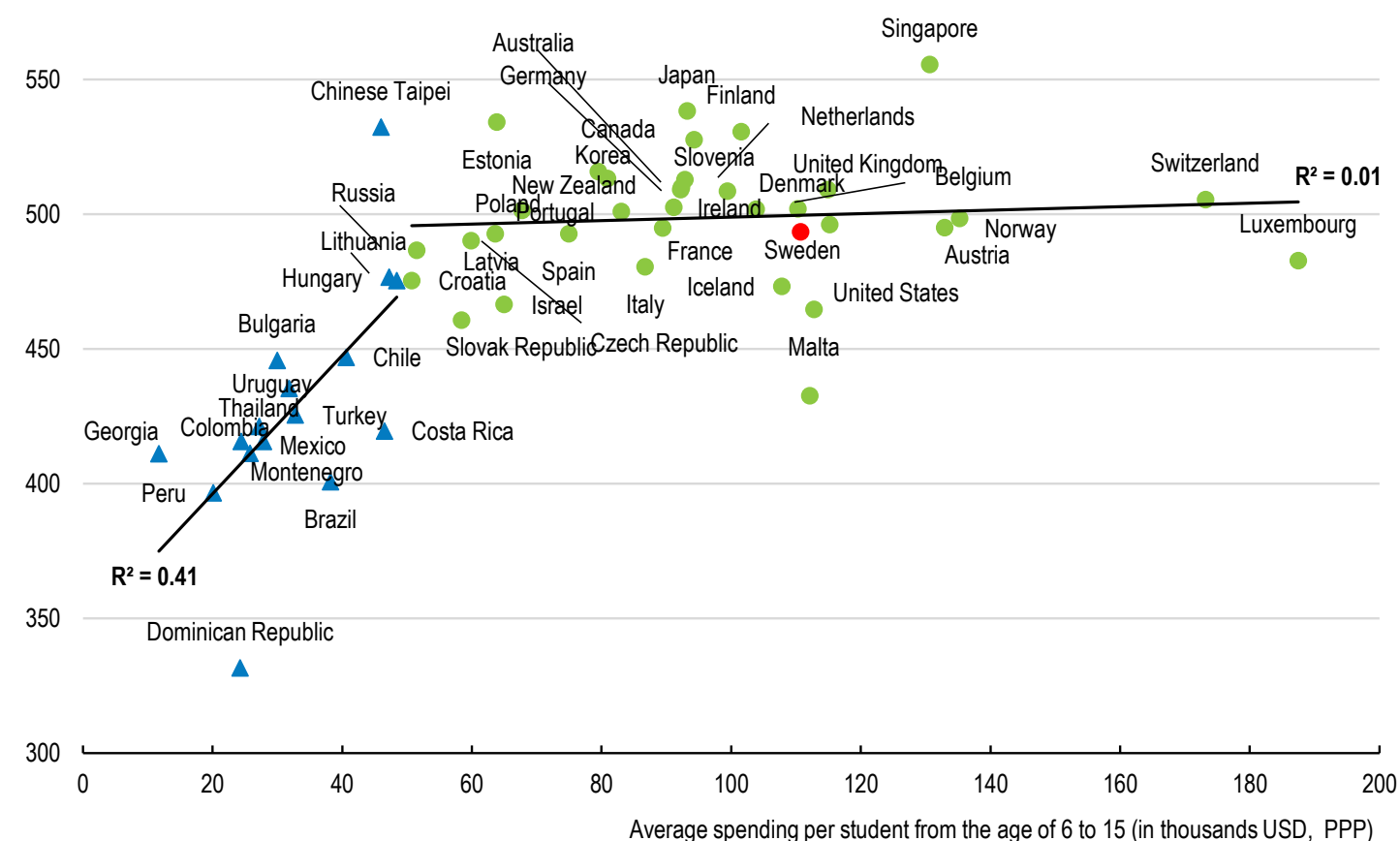

Note: Only countries and economies with available data are shown. A significant relationship $(\mathrm{p}<0.10)$ is shown by the line.

Source: OECD, PISA 2015 Database, Tables I.2.3 and II.6.58.

StatLink त्गाड़ https://doi.org/10.1787/888933944405

Spending levels per pupil and the distribution of resources within the municipality vary considerably because of the decentralised funding model. Furthermore, the socio-economic profile of a school is associated with the school principal's concern about the lack or inadequacy of educational material and staff. The gap in shortages between advantaged and disadvantaged schools is higher in Sweden than the OECD average (Figure 1.13). Shifting a larger share of existing school funding to schools with a less favourable mix of pupils would likely improve results in these schools. Such a shift could raise the national average since the performance of these schools is more sensitive to funding levels and teacher quality than schools with a more favourable mix of pupils (André, Pareliussen and Hwang, $\left.2019_{[7]}\right)$. Better pay does play a role to attract and retain high-quality teachers in schools with higher needs (Glazerman et al., 2013 $3_{[33]}$ ), but should also be accompanied by other measures to improve working conditions in such schools (Hanushek, Kain and Rivkin, $\left.2004_{[34]}\right]$. Across countries, almost all school systems where socio-economically disadvantaged schools report considerably more concern about the material resources at their school than advantaged schools score below the OECD average in science (OECD, $\left.2016_{[32]}\right)$. 
Figure 13. Schools with weak socio-economic backgrounds lack materials and teachers

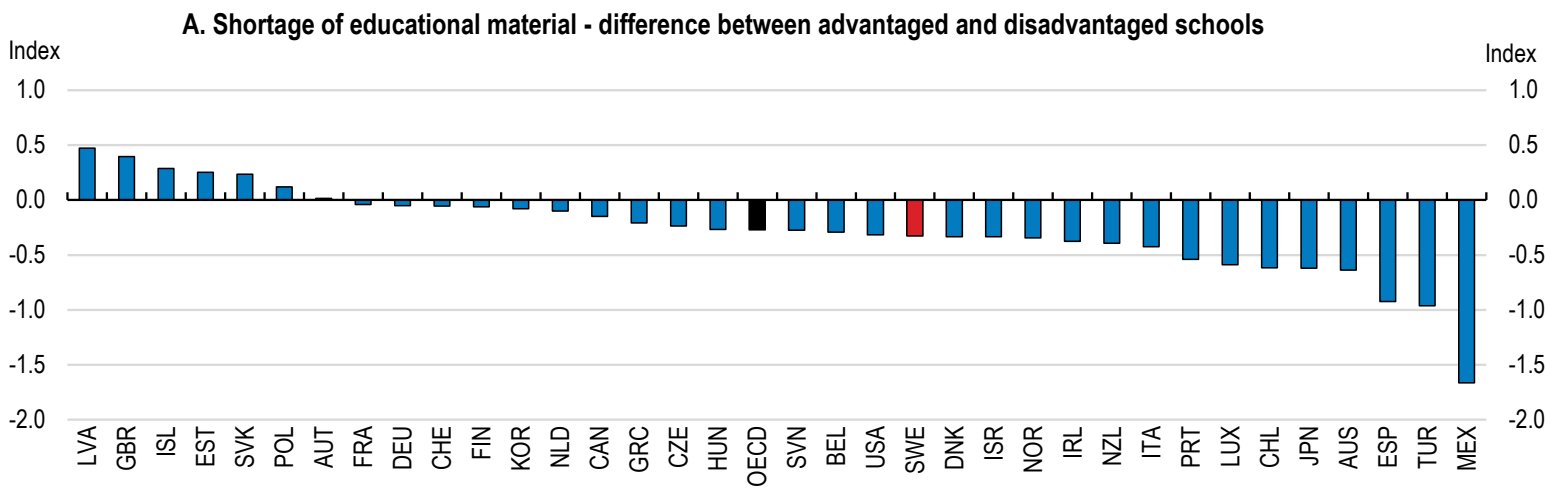

B. Shortage of educational staff - difference between advantaged and disadvantaged schools

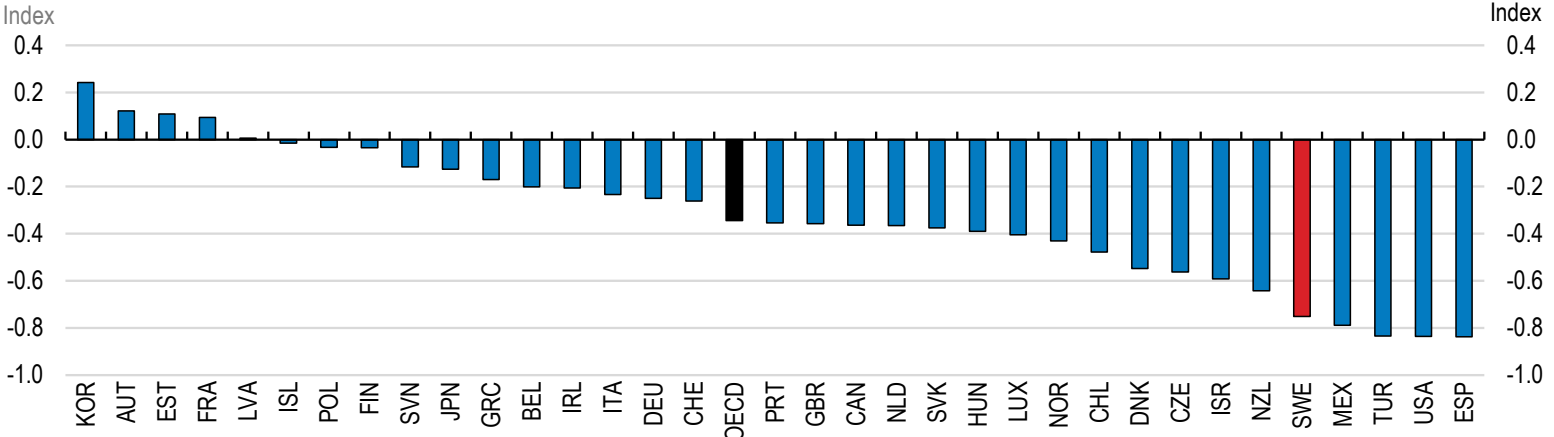

Note: Negative values indicate higher shortages in schools with low socio-economic status. As reported by school principals.

Source: OECD, PISA 2015 Database, Tables II.6.2 and II.6.15.

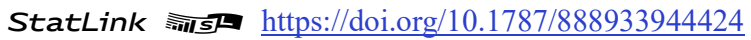

Increased income inequality and immigration have raised the need for compensatory funding, but the share of total funding targeted to compensate for socio-economic disadvantage stayed relatively constant throughout the 1990s and 2000s. Teachers tend to move away from schools with a less favourable mix of pupils as they gain enough experience to compete for positions in schools with a more favourable mix, where work is easier and pay is higher on average. Furthermore, only $74 \%$ of Swedish teachers surveyed in TALIS in 2013 reported that their school provides extra assistance to pupils in need, the second lowest share in the OECD after Mexico (OECD, 2015 $[15]$; OECD, 2014 $[35]$; Holmlund et al., 2014 $[25]$ ).

The central government should take control of a considerable part of school financing in order to improve access to material resources and high-quality teachers (including special needs teachers), in schools that need it most. More compensatory financing would facilitate high-status, attractive and well-paying career pathways linked to schools and classes with a challenging mix of pupils.

The Government is currently phasing in a grant to increase compensatory funding following the School Commission proposal. When fully phased in, the block grant will according to the Commission's proposal reach about SEK 6 billion, which constitutes about $6 \%$ of compulsory school funding. To ensure the desired compensatory effect, 
municipalities and private school providers need to apply for this grant and commit not to reduce their own funding for teaching and pupil health. The grant is calculated on the basis of a socio-economic index value developed by Statistics Sweden, and this index will also guide municipalities in how to distribute resources to their school units (School Commission, 2017 [3] ).

From a political economy perspective, the School Commission proposal has the advantage of reforming compensatory funding without any real changes to the current funding model. The grant is based on voluntary applications, as was already the case for other targeted grants, and does therefore not encroach on the remit of municipalities and private school providers. However, both municipal and private providers have incentives to reduce the funding they provide to their own schools upon receiving such a grant, and effectively verifying that they do not will likely be challenging and bureaucracy-heavy. Alternative or supplementary solutions giving the central government direct oversight over compensatory funding should be considered.

A non-binding minimum funding norm at the school level, based on a socio-economic index could reinforce the effects of the block grant, or perhaps remove the need for a block grant altogether. Municipalities should be compensated for additional cost pressures from funding schools according to the norm through the general system for income-and-cost equalisation between municipalities. Taking the socio-economic mix in compulsory school into account in the income equalisation system should be feasible, as socio-economic conditions are already taken into account for the cost equalisation of other services, such as pre-school services and elderly care (SKL and MoF, 2008 $\left.{ }_{[36]}\right)$. The recent Cost Equalisation Commission agreed to such a solution in principle, but chose not to recommend it, because the Riksdag (Parliament) had already passed the implementation of the compensatory grant proposed by the School Commission, and double instruments might imply double compensation to municipalities for the socio-economic mix in schools (Cost Equalisation Commission, 2018[37] $)$. Denmark takes the socio-economic conditions of school age children explicitly into account in municipal income equalisation, which has led municipalities with a relatively disadvantaged socio-economic population to spend more resources on education than average (OECD, 2016[38]).

Alternatively, the central government could take back responsibility for a substantial part of school funding, to be distributed directly to schools based on a socio-economic index like the one already in use for the block grant. Municipalities would still be free to top up school funding, leaving them with the discretion to prioritise schools against other tasks and to prioritise between schools.

\section{A strengthened regional structure for governance and cooperation}

Decentralisation gave municipalities the full responsibility for running well-performing and equitable schools, which included catering to special needs and developing their teachers' knowledge, skills and careers. In hindsight, it was not reasonable to assume that every municipality had the necessary administrative capacity, expertise and management and control systems. These tasks were previously coordinated by county education boards (Länsskolnämnd), the local arm of the central government school structure, up until decentralisation in 1991, when the education boards were discontinued. These boards also systematically worked towards raising educational quality, provided further training for teachers and ensured local and regional cooperation (Gustafsson, Sörlin and Vlachos, $\left.2016_{[2]}\right)$. 
The decommissioning of the education boards left a void. The need for a central institution with a strong regional presence and with the incentives, competences and authority to systematically work to develop and uphold high quality and equity in Sweden's schools has been emphasised by the OECD $\left(2015_{[10]}\right)$, Gustafsson, Sörlin and Vlachos, $\left(2016_{[2]}\right)$ and the School Commission (2017 $[3]$ ).

The School Inspectorate and the National Agency of Education are natural potential starting points for building up such an organisation. The Inspectorate is a central government agency with five regional offices and extensive experience with school inspections. OECD $\left(2015_{[10]}\right)$ proposed to strengthen and expand the role of the Inspectorate to pivot away from inspections focussed on legal compliance, towards more critical identification of strengths and weaknesses, follow-up, promotion of networking and robust self-evaluations at school, municipal and private school provider level. This would considerably broaden the role of the Inspectorate and would require additional resources. The Education Agency already has the national responsibility for many of the tasks that would become such a regional arm of central government, but does not have a regional presence today. Building up such an organisation would require close cooperation between the two agencies, and with stakeholders, such as teacher and principal unions and the Swedish Association of Local Authorities and Regions.

Municipalities currently offer training opportunities to a varying degree and with varying quality. A strengthened regional structure is key to a more systematic and uniform approach to the continuous development of teachers' skills and competencies, as discussed later in this paper (School Commission, 2017 $[3]$ ).

Decommissioning the education boards removed an important arena for cooperation between schools and school providers. Shifting the main system of school governance from central steering to municipal steering and competition also eroded local incentives for schools to cooperate. A central role of a strengthened regional structure should be to encourage school-to-school and teacher-to-teacher collaboration, which can be an important element in educational improvement (OECD, 2015 $5_{[10]}$; Gustafsson, Sörlin and Vlachos, 2016 $6_{[2]}$; School Commission, 2017 ${ }_{[3]}$ ).

Labour markets are regional, and fostering a closer match between the supply of skills and what is demanded by working life calls for national and regional coordination. A strengthened regional school structure could play a central role in a reorganisation of upper secondary school. A public inquiry has been appointed to investigate this issue. Upper secondary school is, like compulsory school, organised by municipalities and private providers. Even though there is already extensive voluntary cooperation between municipalities, this model is inefficient. It creates problems with funding, since the municipality of residence is as a rule obliged to pay the municipality or private provider where their resident pupils are enrolled an amount calculated on the basis of actual costs or the cost of organising the same programme in public schools in the municipality of residence. With 18 different national programmes and various specialisations within programmes, these rules leave considerable room for interpretation, and litigation over funding is commonplace. Students entering upper secondary school take a more active part in the school choice decision than pupils in compulsory school, and there are signs of overestablishment of some programmes in demand by students but not by employers. This calls for better coordination at the national and regional level, including more active steering of the establishment of private schools (Gustafsson, Sörlin and Vlachos, 2016 [2]; School Commission, 2017 $[3]$ ). 


\section{Clear lines of responsibility and accountability to foster efficient organisation and implementation}

The quality of organisation is strongly correlated with school results in Sweden (André, Pareliussen and Hwang, 2019 $\left.9_{[7]}\right)$. However, organisational quality varies substantially, since more than two thirds of decisions are taken at school and municipal level (Figure 14), and lines of responsibility are unclear. National steering is based on broad direction from the government through notably the Education Act and the National Curriculum, supported by the National Agency for Education and the School Inspectorate. Municipalities, private school providers, principals and teachers interpret and elaborate these centrally defined objectives (OECD, 2015 [15]; OECD, 2015 [10]).

Figure 14. Most decisions are taken at school or municipal level

Percentage of types of decisions about public lower secondary education taken by each level of government (2017)

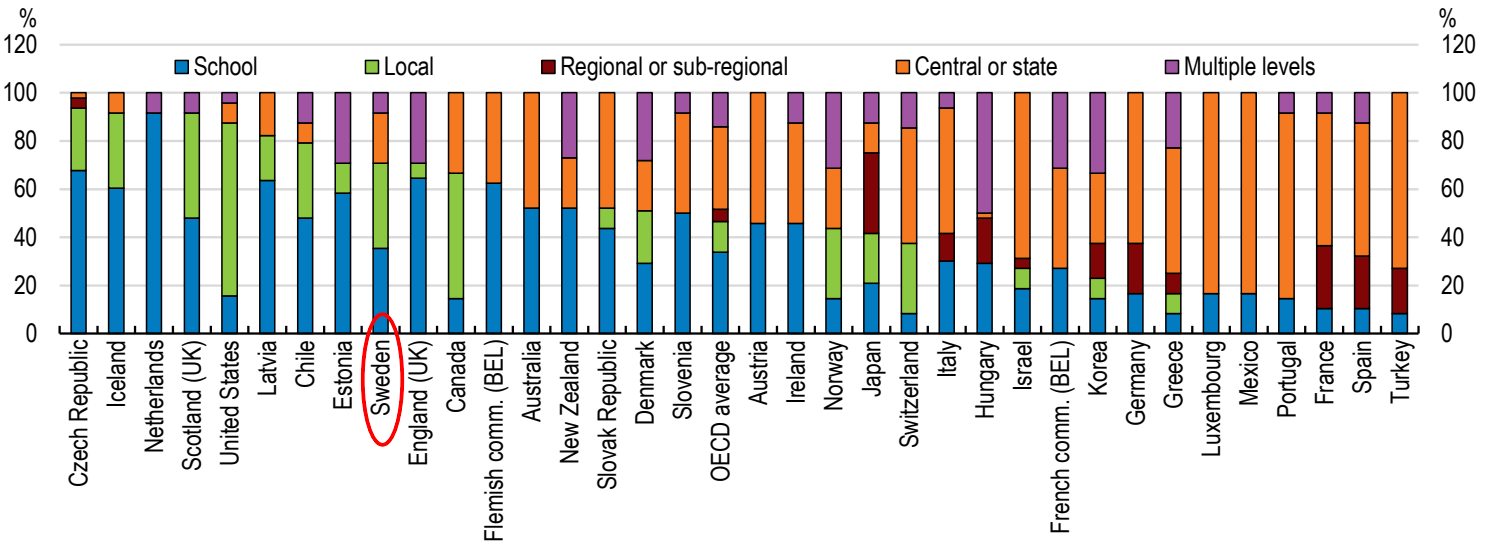

Source: Education at a Glance 2018: OECD indicators, Table D6.1.

StatLink त्ताs https://doi.org/10.1787/888933944443

For management by objectives to deliver, national goals must be established that are broad enough to allow for local interpretation and adaptation but also specific enough to maintain common overall direction. However, key requirements of the Swedish Education Act and the National Curriculum are often seen as aspirational goals at the local level (OECD, $2015_{[10]}$; OECD, 2015 $\left.[15]\right)$.

Teachers and principals presumably want to help their pupils succeed in school, and they are indeed responsible for the results of their pupils according to the Education Act and the National Curriculum. However, the national agenda can become diluted if those responsible for delivery perceive the scale of demands to be unrealistic, or if they are not given the means to succeed. Teachers receive directives from different levels of government, some of them conflicting. In this situation, where teachers and/or principals are not given the means, autonomy and authority to perform in accordance with the set objectives, they may not assume responsibility for the results. Resources aligned with needs and a strengthened regional school structure along with less red tape and better support from colleagues and superiors are important enabling factors (OECD, 2015 $[10])$.

Furthermore, teachers, principals, municipalities and private providers should be held accountable. The example of Essunga municipality illustrates how results can be improved by establishing clear lines of responsibility, among other measures (Box 4). 


\section{Box 4. Essunga municipality: school failure was turned into success in three years}

Nossebro skola, the only school for grades 6 to 9 in Essunga, a municipality of approximately 5600 inhabitants in the south-west of Sweden, ended up almost at the bottom when the Swedish Association of Local Authorities and Regions published their first ranking of school results in 2007. By 2010, however, the ninth graders of the municipality had climbed to third place in the same ranking. This success was largely the result of several steps taken to overhaul the way schools were run in the municipality, although some exceptional circumstances also played a role.

\section{Accountability}

The shock from the low ranking prompted all the actors in the school system to take responsibility, from politicians to teachers and pupils. The municipal education board instructed the head of administration to improve effectiveness and goal fulfilment. The municipality spent slightly below the national average per pupil, and no extra funding was assigned to turn schools around. One of the headmasters in the municipality was given a clearly defined operational responsibility to turn the municipal schools around as "Primary School Head". He had a strong mandate, and used this to place supportive staff in key positions in the initial phase of the turnaround. He implemented the task together with one of the municipality's special education teachers under the motto "Pupil success - the school's responsibility".

\section{Inclusion}

Teachers had routinely put pupils judged to have special needs in separate special needs classes, from which they almost never re-entered normal classes. Now they were assigned a clear responsibility for the success of every pupil, and given the means to deliver. Special needs teachers, now freed from teaching the dissolved special needs classes, instead doubled up with subject teachers during lessons in the core subjects. Extra help was offered to all pupils on a voluntary basis through vacation classes and assisted homework sessions twice a week.

\section{Peer collaboration and learning}

Relevant research literature was reviewed and summarised by the Primary School Head and the special education teacher before it was presented and discussed in mandatory staff seminars. The new way of working, with doubling-up of staff in the core subject classes, forced peer-to-peer collaboration between subject teachers and special needs teachers. These two aspects seeded a culture of discussion, cooperation and peer-to-peer learning in general, leading to the use of a greater variety of teaching methods, suitable for pupils with different needs.

\section{Changes in the classroom}

Pupils were also made responsible. A clearly stated ambition that they succeed in school was coupled with an equally clear expectation that pupils do their part to succeed. This ambition was concretised by clear structures and expectations in the classroom, for example with a starter activity written on the whiteboard from the start of the lesson.

Source: Persson (2013 [30]). 
Clearer responsibility for key outcomes and peer pressure within the profession can in turn reduce the need for detailed regulations and inspections, and thus enable administrative simplification for principals and teachers.

\section{Steering competition and choice}

Drawing the benefits from choice and competition, while limiting negative side-effects calls for addressing information asymmetries, and taking the socio-economic mix into account in compulsory school entry and when investing in new schools. Without sufficient steering, a school system based on competition for pupils will only deliver in line with the public good if private interests match the public interest and perfect information is available to parents and pupils. These assumptions are not met in Sweden and can in principle never be fully met. Educational quality cannot be accurately measured, and pupils and their parents will also value other aspects of a school, such as a homogeneous group of pupils, lenient grading easing entry to further education, good pupil-teacher relations, particular school profiles or modern buildings and equipment (Gustafsson, Sörlin and Vlachos, $2016_{[2]}$; OECD, 2015 $\left.[15]\right)$.

School segregation reflects wider societal trends, notably rising income inequality and immigration, which underpin residential segregation. However, school choice and private provision, as implemented in Sweden today, increases school segregation. Segregation risks reducing equality of opportunity and risks lowering the overall performance of Swedish schools due to peer effects, as pupils with weak socio-economic backgrounds may lose more from school segregation than pupils with strong backgrounds gain (Holmlund et al., 2014[25]; Gustafsson, Sörlin and Vlachos, 2016[2]; Sund, 2009 [20]). The OECD has identified facilitating the access of immigrants to school choice as a priority area for closing the gap between immigrant and native pupils in Sweden, along with building teaching capacity, providing language training and strengthening the management of diversity (Cerna et al., 2019[39]).

School providers receiving public financing in the Swedish system, be they private or public, are not allowed to charge tuition fees. The profits of for-profit school providers will hence depend on their ability to contain costs. Costs can be contained by providing quality education more efficiently than public schools, for example with more efficient teachingand management practices and shorter, more responsive chains of command. However, costs can also be contained in ways that reduce education quality, for example by hiring fewer and less qualified staff, as long as the school stays attractive to pupils. Empirical results indicate that both these mechanisms apply (André, Pareliussen and Hwang, 2019 $9_{[7]}$ ). Incentives to cut costs at the expense of quality force the authorities to define a detailed set of rules and implement a strict enforcement regime. The logic of the system becomes one of compliance with minimum requirements, rather than systematic work for continuous improvement (Gustafsson, Sörlin and Vlachos, 2016 ${ }_{[2]}$; OECD, 2015 ${ }_{[15]}$ ).

The Swedish system is unique in the OECD context. Many countries have a large share of private schools dependent on public funding, but only Sweden and Chile had large publicly funded for-profit sectors in 2015 (Figure 15). Chile ended public funding of for-profit schools on equity grounds with the 2015 Inclusion and Equity Law (OECD, 2018 $\left.{ }_{[40]}\right)$, leaving Sweden as the only OECD country with a substantial for-profit school sector funded by the public purse. The private school sector is growing strongly in Sweden (Figure 16), and growth is almost exclusively in the for-profit segment (Werne, 2018 ${ }_{[41]}$ ). Charter schools at the sub-national level of the United States also bear strong resemblances to the Swedish system. 41 states and the District of Columbia permit charter schools to 
operate. Charter laws vary across states, but defining characteristics common to the Swedish system are that that they cannot charge tuition fees, and they are not permitted to impose admission requirements. If over-subscribed, they must select pupils by lottery. Even though charter schools do not outperform public schools on average when controlling for pupil backgrounds, many charter schools, and charter school districts (such as New York City) appear to outperform traditional public schools according to various measures, and individual schools and the sector as a whole seem to improve over time (Epple, Romano and Zimmer, 2016 $[42])$. Several states have school voucher programmes or tax credits to offset the cost of attending private schools. These programmes often raise the results of their direct beneficiaries, notably when targeted towards groups of low socio-economic status (Anderson and Wolf, 2017 $[43]$ ). However, it is not clear whether the improvements reflect higher school productivity or peer effects, and the system-wide effects of these voucher programmes remain uncertain (Urquiola, 2016[44]).

Most other OECD countries limit dividends and/or limit entry of for-profit school providers. For example, the Czech school system opened up for private provision in the early 1990s as in Sweden, and a high share of private schools in the Czech Republic depend on public funding as a result. However, entry criteria for schools receiving public funding were tightened in a 1995 law, they are not allowed to be run for profit, and public funding does not cover investment expenditure $\left(\mathrm{OECD}, 2016_{[45]}\right)$. Denmark has a relatively large private school sector, funded with a voucher system resembling the Swedish one. However, publicly funded Danish private schools are non-profit, they receive only slightly above $70 \%$ of the average cost per pupil in public schools, and they are allowed to charge tuition fees (OECD, 2016 $\left.6_{[38]}\right)$. The Netherlands is another example with strong similarities to Sweden. Entry of private providers is liberal, and private schools are funded equivalently to public schools, but in contrast to Sweden, only non-profit providers receive public funding (Box 5).

Figure 15. The scale of publicly funded for-profit schools is unique in Sweden

Share of 15-year olds attending private schools (2015)

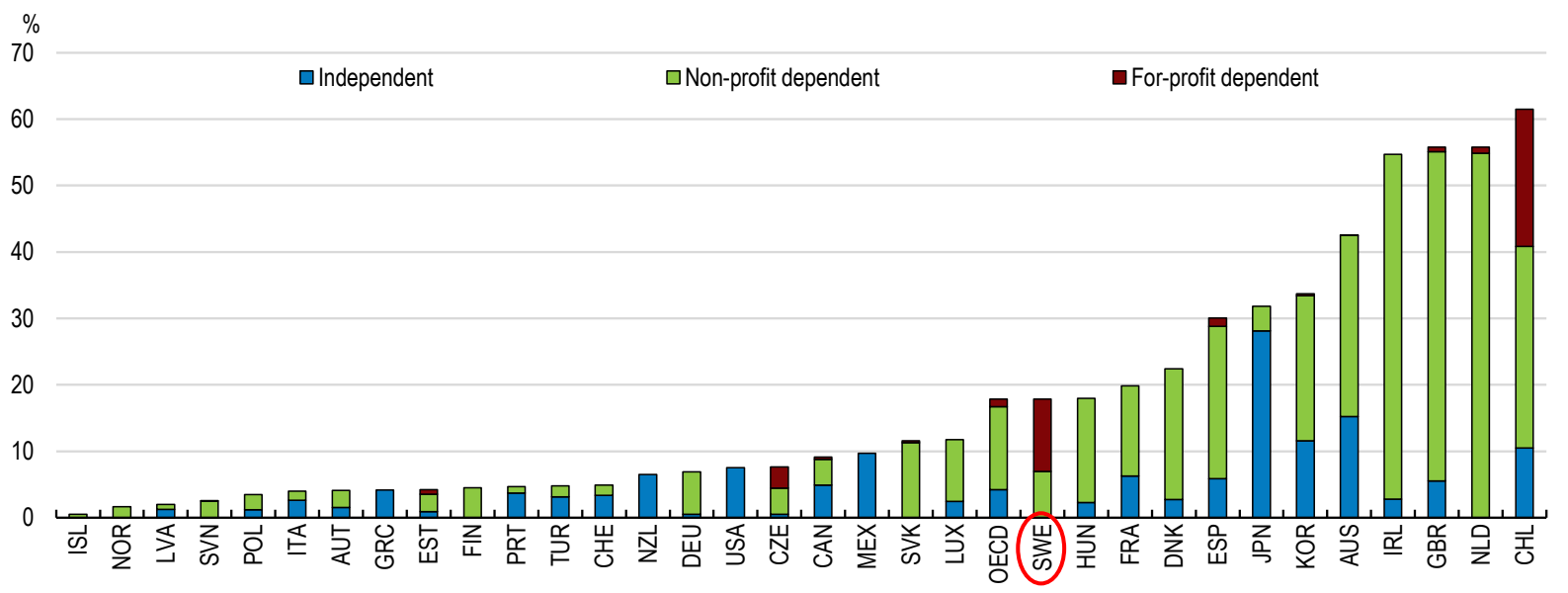

Note: Dependent schools receive at least $50 \%$ of their funding from public sources. Chile's Inclusion and Equity Law, passed in 2015, ended public funding of for-profit schools.

Source: OECD (2016[32]).

StatLink त्ञाI 
Figure 16. A rising share of pupils attend publicly-funded private schools

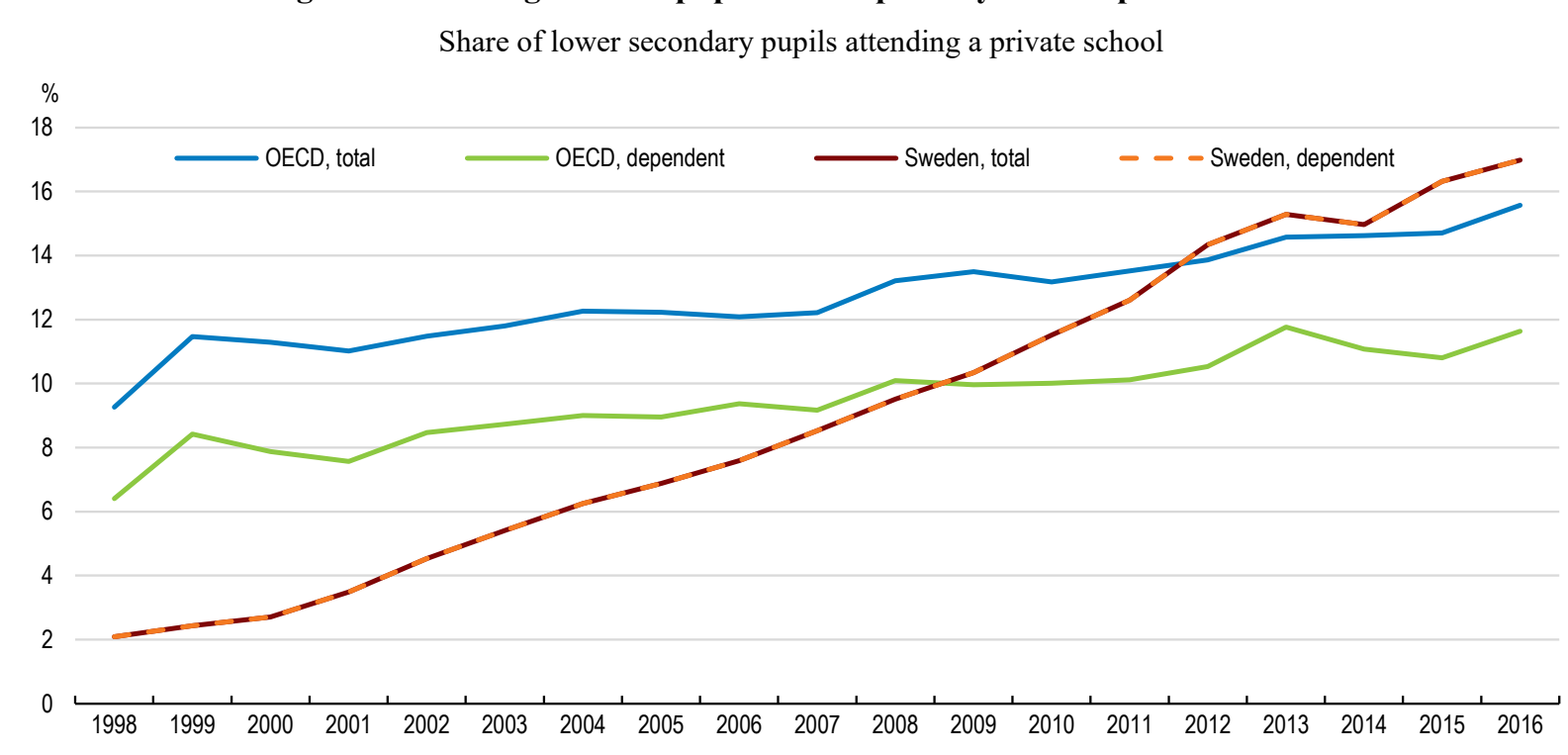

Note: Dependent schools receive at least $50 \%$ of their funding from public sources. The Netherlands is excluded from the OECD total, as the Dutch private (non-profit) school sector is classified as part of the public sector from 2005 in the source data.

Source: (OECD, 2018[46]).

StatLink त्ञात् http://dx.doi.org/10.1787/888933944481

The Swedish system should not reform just because it is different. Private competition in the provision of certain public services can be a useful tool to address cost pressures and improve quality, when accompanied with the right steering and regulations. Some aspects of the current system seem to work well. For example, the most profitable for-profit schools also show the best results across a range of outcomes when compared to other for-profit schools (Heller Sahlgren and Jordahl, 2018[47]), and private schools seem to be more responsive to pupil needs than public ones on average (André, Pareliussen and Hwang, $\left.2019_{[7]}\right)$.

However, the systemic effects of competition are more unclear. PISA shows no relationship between competition and results in cross-country comparisons (OECD, 2016 $6_{[4]}$ ). Competition and choice as implemented in Sweden increases school segregation (Skolverket, 2018 ${ }_{[6]}$; Böhlmark, Holmlund and Lindahl, 2016 $[21]$; Yang Hansen and Gustafsson, 2016[22]). Furthermore, there is no evidence that it increases average results. Private schools tend to perform well compared to public schools, but mostly because these schools attract pupils with more favourable backgrounds. For-profit schools underperform public schools on average when controlling for socio-economic backgrounds and other relevant variables, even though many of them are high performers. They are notably weaker than public schools in catering for pupils with weaker backgrounds (Figure 17) (André, Pareliussen and Hwang, 2019 ${ }_{[7]}$; OECD, 2016[4]; Skolverket, 2018 $8_{[6]}$ ). Competition could still be positive if the mere existence of competitive pressures would raise the average performance of all schools, but empirical studies find such competition effects to be small. Previous studies found small positive effects locally in areas with high competition in Sweden, while OECD work on more recent data finds a small negative effect, significant for the schools with the least favourable socio-economic mix of pupils. These results are consistent with negative peer effects in low-performing schools dominating positive effects 
from competition over time as competition increases school segregation (Wondratschek, Edmark and Frölich, 2013 ${ }_{[48]}$; André, Pareliussen and Hwang, 2019 $\left.{ }_{[7]}\right)$.

One important shortcoming in the current system of choice and competition lies in inevitable information asymmetries, as it is not possible to accurately measure the efforts and effectiveness of individual schools. To further complicate issues, value-added from individual pupils' own efforts are part of the school production function, and it is hence not possible to accurately assign responsibility for outcomes.

Turning national tests into an objective benchmark of skills by ensuring the integrity of test material and independent grading is an important first step to reduce information asymmetries. This objective benchmark of performance would be of great value to school agencies, school providers, teachers, researchers, prospective pupils and their parents. Further developing, disseminating and promoting value-added measures of school performance based on this objective benchmark would also help pupils and parents make better choices. Gustafsson, Sörlin and Vlachos $\left(2016_{[2]}\right)$ propose to use such an objective benchmark to address differences in grading practices by mechanically adjusting schoollevel subject grades by school-level test scores.

Ensuring that grades fairly represent a pupil's skills and knowledge is important, as sorting from compulsory to upper secondary school depends exclusively on grades in Sweden. Grades are also the primary sorting mechanism from upper secondary school to tertiary education, even though it is possible to enter university through the Swedish Scholastic Aptitude Test (SweSAT). However, the grading system puts too high a weight on failure. Moving from the fail grade $F$ to the lowest passing grade $E$ is rewarded with 10 points in upper secondary- and tertiary-intake, while each subsequent step is rewarded with only 2.5 points. The cost of failure is accentuated by the entry requirements to upper secondary education, where a fail grade in either of the subjects Swedish, Swedish as a second language, mathematics and English disqualifies entry into the national programmes. Pupils are in this case entitled to enter a second-chance introduction programme. Chances to succeed in an introduction programme (previously "the individual programme") were slim in the past (OECD, 2015 $[15])$, prompting a reform in 2011, after which the programme has not been properly evaluated. The heavy weight on fail grades and their severe consequences in further school entry strongly incentivises schools and pupils to tilt efforts towards avoiding failure. The system also somewhat arbitrarily triggers failure through threshold effects around the fail grade (Gustafsson, Sörlin and Vlachos, 2016 $6_{[2]}$ ). Weighing high and low grades symmetrically and suppressing the requirement to pass in certain subjects to enter upper secondary education would constitute a more balanced approach towards helping pupils achieve their full potential. High grades would still be necessary to enter the most popular programmes and the most popular schools, but pupils would not be excluded from educational choices predominantly based on their performance in their weakest subjects. Specific programmes could still have narrower grade requirements, for example requiring a minimum grade level in specific particularly relevant subjects. 
Figure 17. Private schools' over-performance reflects pupil selection

A. Private schools attract students with favourable backgrounds $(2017)^{1}$

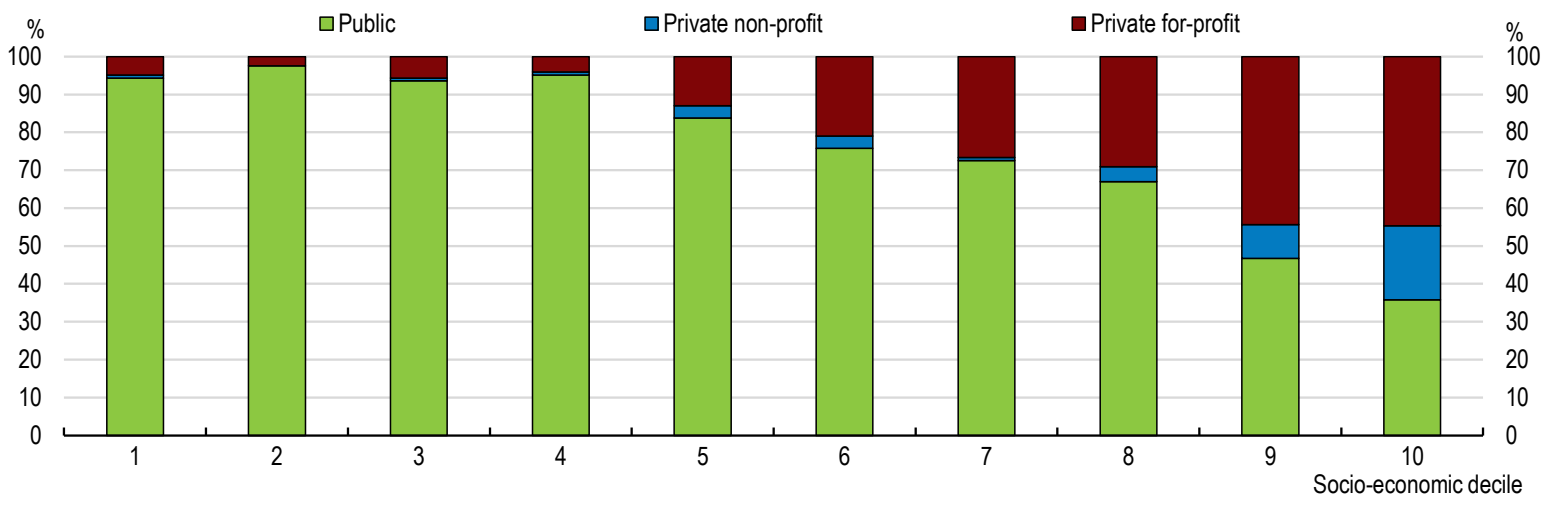

B. Inferior results in for-profit schools controlling for student backgrounds ${ }^{2}$

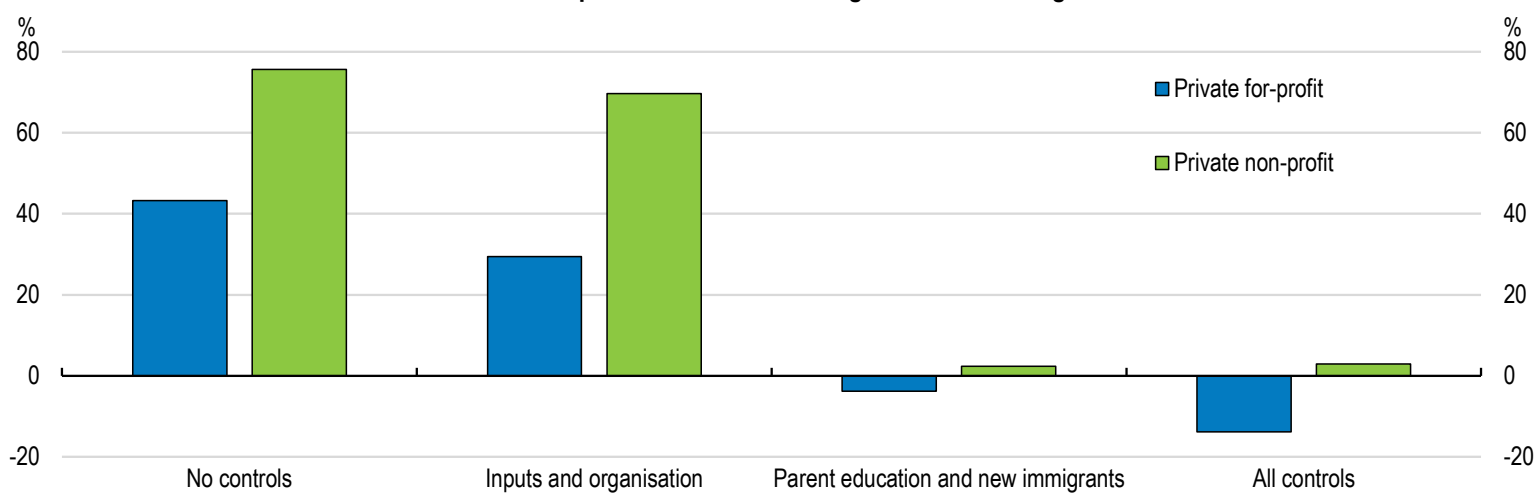

1. The figure shows schools sorted into deciles according to their socio-economic mix of pupils. Schools are not weighted by size.

2. Difference to public schools in the logarithm of national mathematics test scores for $9^{\text {th }}$ graders. The columns are coefficients for private for- and non-profit dummies in a random-effects panel regression with data covering 2013-17. "All controls" corresponds to the main specification in André, Pareliussen and Hwang (2019[7]). "Parent education and new immigrants" controls for the education level of parents and the share of pupils who immigrated during the four years preceding the test. "Inputs and organisation" controls for the average municipal expenditure per pupil, the share of certified teachers, the number of pupils per teacher and a survey measure of adaptation of education to pupils' needs. Source: Authors' calculations based on André, Pareliussen and Hwang (2019[7]).

StatLink त्माs http://dx.doi.org/10.1787/888933944177

\section{Box 5. Competition and school choice in the Netherlands}

The Netherlands has a long tradition of a highly decentralised school system with school choice and a high share of privately run schools. The importance of private schools has increased over the past 150 years, and currently more than two thirds of pupils attend schools run by private school boards. For historical reasons, over half of all schools are either Catholic or Protestant, but there are also schools run by associations or foundations not based on any specific religious beliefs or alternative teaching philosophies. The Dutch school system closely resembles the Swedish one in several ways:

- There is liberal entry of private schools provided they meet the quality standards and conditions imposed by law for the school system as a whole. 
- Pupils and their families can freely chose the school to attend, public or private.

- Funding is public, follows the pupil and is the same for public and private schools.

Contrary to Sweden, the Netherlands has consistently performed well in international rankings, even though results in reading have weakened somewhat since 2003 (Figure 1.18). One important difference with Sweden is that the Dutch system has evolved slowly over multiple decades rather than going through a sudden and fundamental reshuffling of the system, as happened in Sweden in the 1990s. But the current Dutch system differs from the Swedish one in some important ways:

- Funding is primarily given from the central level to individual primary schools. The block grant from the central government is calculated to cover staffing and running costs, with a strong element of targeting according to socio-economic criteria.

- Only non-profit schools are eligible to receive public funding.

- A relatively large central staff includes the Education Ministry and the School Inspectorate, but also a number of school advisory services and coordination bodies.

- Individual schools enjoy great autonomy in how to achieve centrally set attainment targets.

\section{Figure 18. PISA results in reading}

Difference to OECD average

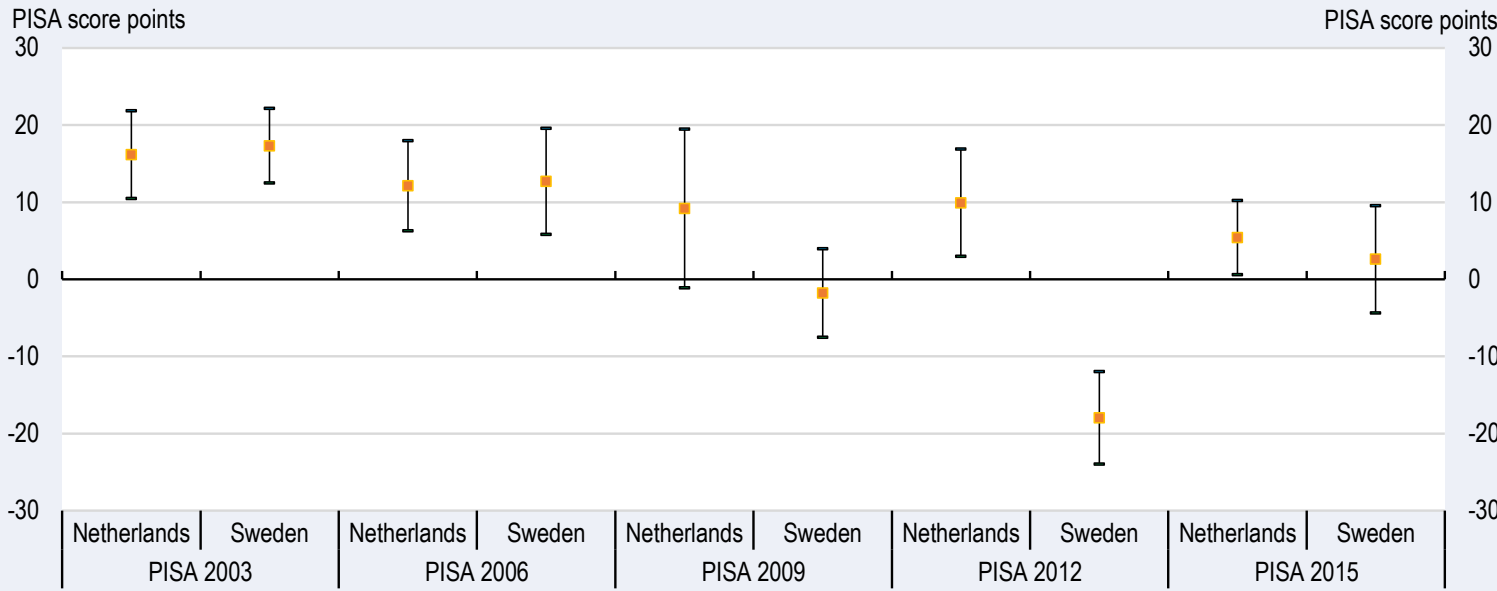

Note: The black vertical lines denote the $95 \%$ confidence interval. OECD average refers to the average for the 24 OECD countries participating in PISA 2000.

Source: OECD (2016[50]), Patrinos (2011[51]) and OECD (2016[4]), Table 1.4.4a.

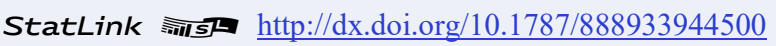

Even with grades better reflecting skills and improved information about the value added by individual schools, individuals choose schools based on their own priorities, which do not align perfectly with the best interest of society. In the Swedish system, where funding follows the pupil, schools are forced to respond to competitive pressures, even if this means giving pupils and parents what they want, rather than what they need and what society needs (Gustafsson, Sörlin and Vlachos, 2016 [2]; Dahlstedt and Fejes, 2018 [29]).

The possibility for pupils and their parents to choose which school to attend has an intrinsic value, and there is scope to counteract segregation without taking away this opportunity. However, it is important to recognise that school choice does not mean, even today, that 
every pupil gets to attend his or her first choice, but rather that parents and pupils have the right to state their preferences and expect these preferences to be part of a set of deciding factors within the applicable rules.

In today's system, parents can choose to apply for a certain school and pupils have a right to a place in a municipal school within reasonable proximity to their home. Selection into over-subscribed municipal schools is regulated by the municipality, while selection into private schools is regulated by the private school provider, usually based on queuing time. School choice is usually exercised by (the parents of) pupils from more advantaged backgrounds, many of whom choose private schools at least partially because of a more homogeneous and advantaged pupil mix (Malmberg, Andersson and Bergsten, 2014 [49]; Holmlund et al., 2014 $[25]$ ). The system is obviously unfair to new immigrants and pupils who have moved, as queuing times can be several years for the most popular schools. Schools are not allowed to apply directly discriminative selection criteria, but they can affect which pupils they take in by their physical location, their marketing profile, and of course by the queuing system (Gustafsson, Sörlin and Vlachos, 2016 ${ }_{[2]}$; Dahlstedt and Fejes, 2018[29]).

Public and private school providers have different missions within the current school system. Municipalities are obliged to offer a school place to every resident child of the municipality, in reasonable proximity to their home, and to provide transportation if necessary. Private providers have no such obligations. They are established at the discretion of owners and attended at the discretion of pupils and parents. Placing the entry procedures of private schools strictly under municipal control would allow for a coordinated school intake that would facilitate municipal efforts to counteract segregation. However, given the significant vested interests in the current system, notably from private school providers and well-off parents, reforms probably need to maintain the current differentiation between public and private providers to maximise the likelihood of success.

The Education Act sets out the proximity principle, that pupils have the right to schooling relatively close to their home. Municipalities generally interpret this principle strictly, seeking to minimise pupils' walking distance to municipal schools. A first step to reduce segregation is to clarify municipalities' responsibility to take the socio-economic mix into account when drawing catchment areas, along with reasonable proximity. To the extent the current law does not allow such an interpretation of the proximity principle, the law should be amended. The government proposed in 2018, based on a recommendation from the School Commission, to give education providers an obligation to work actively towards a diverse socio-economic composition of pupils in their schools. The proposal was voted down by the Riksdag.

School segregation should also be counteracted with municipal localisation decisions when investing in new school capacity to meet the coming surge in pupils (OECD, 2015 $[10])$. However, for localisation decisions to effectively counteract segregation, some coordination between the municipality and private providers is needed. Concerns as to how applications for new permits to independent schools would affect the schools in the municipality is already a factor for consideration when granting new licences. However, such factors should perhaps have a higher influence on the outcome, notably considering the possible effect on school segregation when giving permits to open new schools, expanding pupil numbers or taking over existing ones, and giving municipalities a stronger say in these decisions.

A re-interpretation of the proximity principle should be the primary tool to counteract segregation to over-subscribed municipal schools, but would not affect intake to private 
schools, which is under the discretion of the school provider. The queuing system is unfair because it favours pupils from strong socio-economic backgrounds, and it discriminates against internal and external immigrants. School places in over-subscribed schools should be assigned by lottery, or with quotas reserved for pupils with unfavourable socioeconomic backgrounds. Earlier proposals of abandoning queuing time for a lottery, for example by the School Commission, were met by fierce resistance. Assigning places by queuing time within socio-economic background quotas might be somewhat less contentious, with reserved places for pupils newly arrived to the municipality, pupils with low-educated parents and/or with immigrant background. Successful examples of school choice with socio-economic quotas exist in Nijmegen in the Netherlands and Flanders in Belgium (OECD, 2015 [10]; School Commission, 2017 $\left.7_{[3]}\right)$.

\section{Improving teacher education and the attractiveness of the profession}

Teacher quality has a substantial influence on learning, and this effect tends to be larger for pupils with low socio-economic status (Nye, Konstantopoulos and Hedges, 2004 [50]). Even though the importance of good teachers (and principals) is clear, it is less clear which factors make a good teacher (Björklund et al., 2010 $\left.0_{[51]}\right)$. Observable characteristics such as content-specific education, pedagogical qualifications and experience are often used in empirical work, but with varying results. André, Pareliussen and Hwang $\left(2019_{[7]}\right)$ find a positive correlation between teachers' content knowledge, i.e. their formal qualifications to teach the subject in question, and school test results. However, teachers tend to prefer schools with more advantaged pupils, where the work is easier and the pay tends to be higher (Holmlund et al., 2014 ${ }_{[25]}$; Karbownik, 2014 ${ }_{[52]}$ ). When controlling for this endogeneity with an instrumental variable approach, the positive effect of the share of certified teachers in André, Pareliussen and Hwang (2019 $\left.9_{[7]}\right)$ loses significance. Conversely, with a more detailed dataset covering the years 1998-2004, Andersson and Waldenström $\left(2007_{[53]}\right)$ are able to use more sophisticated econometric techniques and find that the share of subject-certified teachers is positively related to results. André, Pareliussen and Hwang $\left(2019_{[7]}\right)$ also find a particularly strong correlation between teacher qualifications and results for schools in the bottom part of the socio-economic distribution of schools, which points to the importance of attracting and retaining teachers in the schools with the greatest needs.

Even though observable differences in education and experience do not always explain teacher quality in empirical work studying a cross-section of teachers, this does not mean that teacher education and training is of no importance. It rather means that teacher quality is much more complex than what can be easily measured by these observable characteristics. Pedagogy, or the ability to teach, is largely a set of practical skills resulting from individual talent, education, experience and practice, obtained both during the initial teacher education and subsequently through learning by doing, continuous professional development and collaboration with peers.

Only 5\% of teachers in Sweden report that teaching is a valued profession in society, compared with 59\% in Finland, 31\% in Norway, 18\% in Denmark, and the Teaching and Learning International Survey (TALIS) average of 31\% (Figure 19) (OECD, 2014 ${ }_{[35]}$ ). The $\operatorname{OECD}\left(2015_{[10]} ; 2015_{[15]}\right)$ has recommended to enhance opportunities for career- and wageprogression. Teachers' wages have increased recently, following years of relative stagnation, and the government introduced a special grant and expanded career pathways with the "First teacher" reform and later the "Teacher salary boost". Employers can apply for the First teacher grant and promote teachers based on their merits within a given set of pre-defined minimum criteria. The First teacher reform and the Teacher salary boost send 
an important signal to teachers that they are valued, and earnings for young teachers are now well above the OECD average.

Figure 19. The teacher profession is unattractive

Percentage of teachers who agree that the teaching profession is valued in society

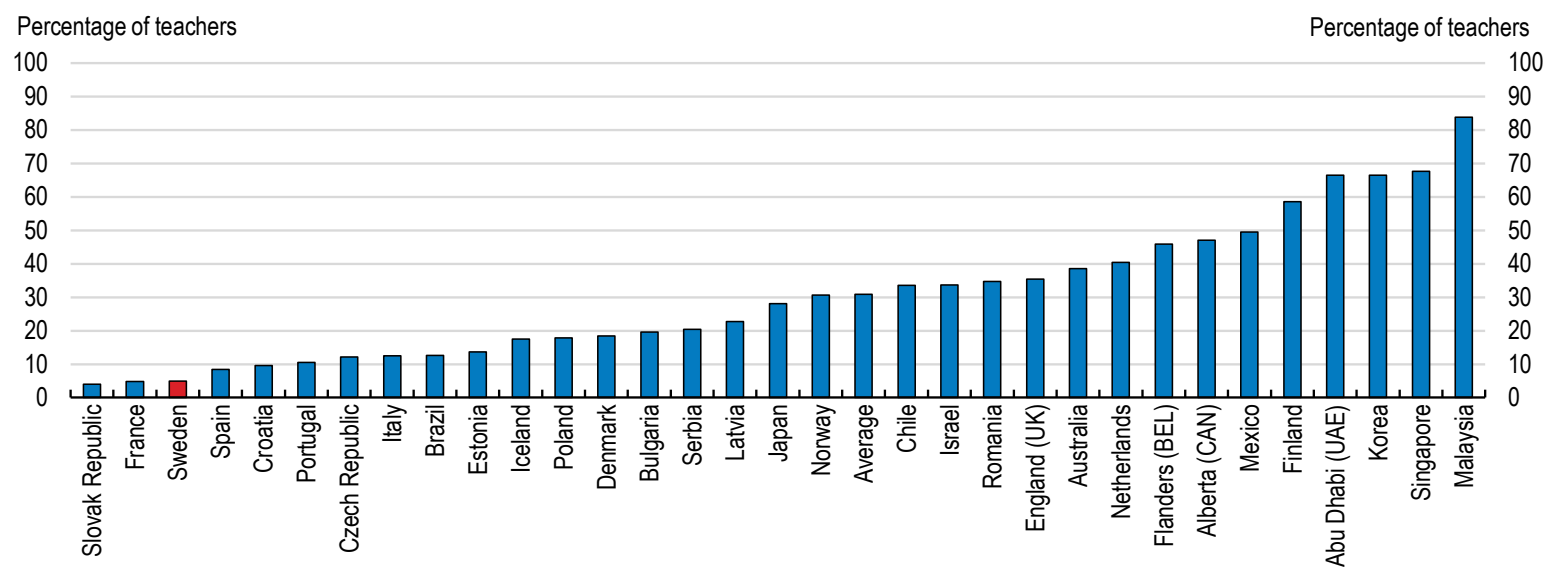

Source: OECD, TALIS 2013 Database, Tables 7.2 and 7.2 web.

StatLink त्माज http://dx.doi.org/10.1787/888933944196

A rigorous education and a strong profession with enhanced collegial cooperation and a strong professional identity would contribute to increasing the attractiveness of becoming a teacher. However, initial teacher education in Sweden is fragmented, with 28 higher education institutions providing initial education programmes. These programmes are largely designed based on the availability of teaching personnel and the demands of applicants rather than emerging needs at the school level. High-performing countries tend to have fewer teacher education institutions. Finland has eight and Singapore has only one (OECD, 2015 $\left.{ }_{[10]}\right)$. Consolidation, by closing down the institutions with the lowest quality of applicants and education, or merging such institutions with higher-performing institutions, might help Sweden increase quality and coordination within the sector, but needs to be weighed against the need to educate more teachers to fill current and projected shortages. Furthermore, a major reorganisation of the teacher education sector should await the on-going evaluation by the Swedish Higher Education Authority. Successful teacher education institutions tend to have a clear vision of what constitutes good instruction, clearly defined educational goals and expectations from pupils. Furthermore, they tend to successfully integrate theory and practice, and a substantial part of education consists of teacher practice in schools (School Commission, 2017 ${ }_{[3]}$; Holmlund et al., 2014 ${ }_{[25]}$ ).

Instruction time in teacher education is low in Sweden, at about 10 hours per week, or less than half of the 25 hours available to doctor- dentist- and pharmacist students. Instruction time should increase. More time should be spent in teacher practice, and there should be a clear integration between practice and practical instruction by experienced teachers and theoretical classes about teaching and learning. However, these measures are labour intensive and would require increased financing (School Commission, 2017 ${ }_{[3]}$ ).

More selective admission criteria to teacher education has been brought forward as a way to improve teacher quality and improve the status of the occupation. Some selectivity may be warranted. A person wanting to teach mathematics might for example be expected to have reached a minimum grade level in mathematics. However, Sweden faces a lack of 
teachers, and more general limitations to enter teacher education might exclude students who would make good teachers despite low grades in some subjects. A better approach would be to make teacher education more rigorous in theory and practice, which would entail a selection during the course of education rather than at the time of entry. A more challenging and rigorous programme would likely be more appealing to high-achieving students.

A strengthened research base, more rigour in theory and practice and more feedback from experienced educators should also be part of a teacher's career after graduation. Continued learning opportunities, coordinated by a strengthened regional structure of the school agencies, should maintain close links to universities and university colleges. University personnel participating in such learning activities would also potentially benefit from closer cooperation with local teachers on research projects and student placements.

Equally important for quality in teaching and teacher development is peer-to-peer collaboration and feedback. Swedish teachers being mentored, observed by peers and coached have a higher sense of self-efficacy and job satisfaction. Systematic mentoring of new teachers would allow them to partake the practical experience of colleagues, and also reduce the risk of early exit from the profession. The example of Essunga municipality (Box 4) illustrates how research-founded peer-to-peer discussions and feedback hold the potential to enlarge the scope for using different teaching methods, which is an important dimension of teacher quality (Krauss et al., 2008 [54]; Björklund et al., 2010 [51]). Feedback and pedagogical leadership from the school principal is an important part of this. However, the Teaching and Learning International Survey (TALIS) shows that principals in Sweden are less experienced than the TALIS average, they report spending $51 \%$ of their time on administration, devoting only $19 \%$ of their time to curriculum and teaching tasks. Moreover, only $7 \%$ have teaching obligations, which may keep them somewhat detached from the core job of the school (OECD, 2014 $\left.{ }_{[35]}\right)$. Most TALIS teachers get feedback from multiple sources, which could be an indicator of teacher collaboration or distributive leadership. However, fewer than average Swedish teachers participate in induction and mentoring activities (Figure 20). Nearly one in three Swedish teachers (32\%) reports never having received feedback. This is a higher share than in the other Nordics, and more than double the TALIS average of $12 \%$. A slight majority of Swedish teachers (57\%) report never observing other teachers' lessons or giving them feedback. Those teachers having received feedback mostly did so only from one source, the principal, who tends to spend most of his or her working time on administrative tasks (Figure 21) (OECD, 2014 [35]).

The learning environment in Swedish science classes is better than the OECD average in terms of noise and disorder, but worse in terms of truancy, as more than half of Swedish pupils taking the 2015 PISA Survey arrived late for school in the two weeks before the test (OECD, 2016[32]). There is potential to improve classroom leadership as part of intensified efforts to build teachers' skills. 
Figure 20. Few Swedish teachers have a mentor

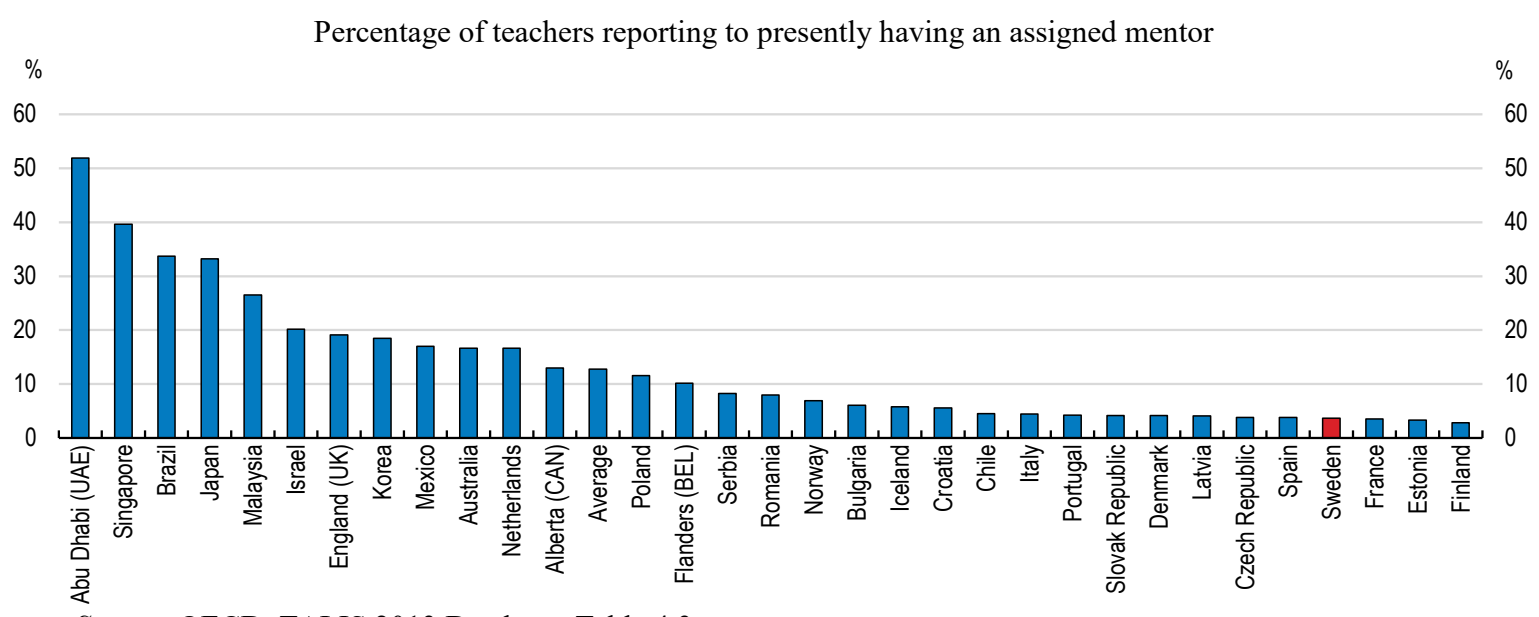

Source: OECD, TALIS 2013 Database, Table 4.3.

StatLink 제내 https://doi.org/10.1787/888933944519

Figure 21. Teacher appraisals and peer-to-peer learning are patchy

Share of lower secondary education teachers who report receiving feedback in their current school

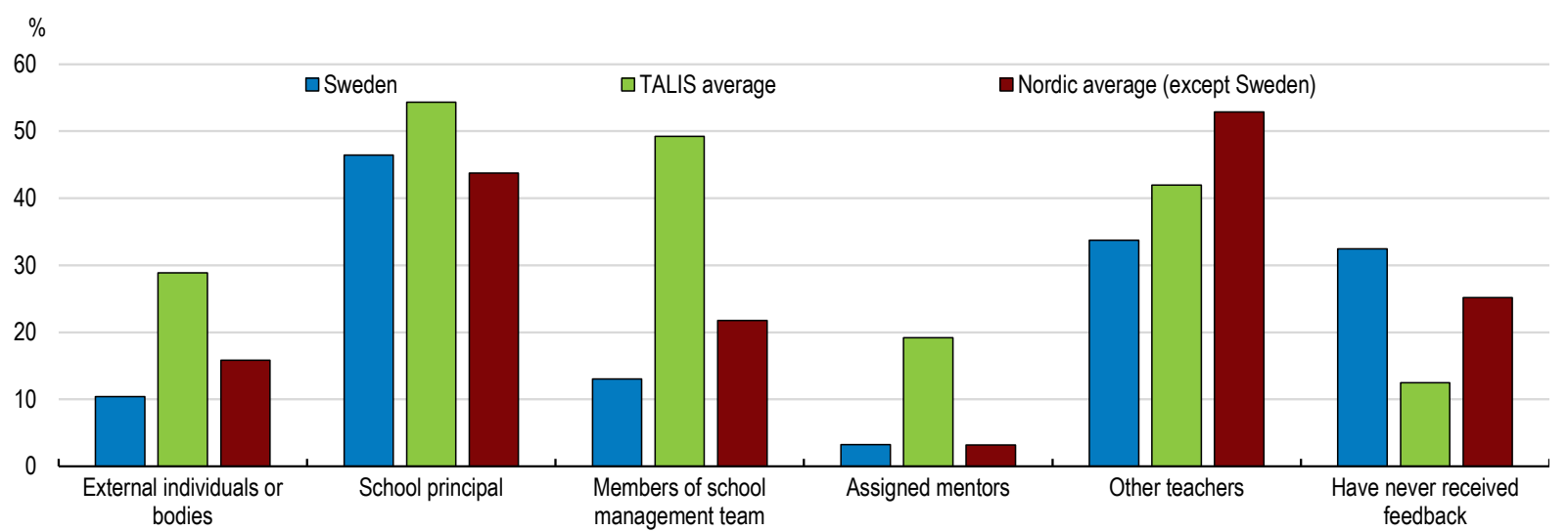

Note: Feedback is defined broadly as any communication of the results of a review of an individual's work, often with the purpose of noting good performance or identifying areas for development. The feedback may be provided formally or informally.

Source: OECD, TALIS 2013 Database, Table 5.4.

StatLink त्गाड़ https://doi.org/10.1787/888933944538

Teachers should face incentives to progress, perform and take on challenging tasks. Strengthened steering from a regional governance structure, clear lines of responsibility and accountability for results should help. However, teacher quality tends to affect pupils with low socio-economic status more than the average, but this is not currently recognised in pay and career structures in Sweden, where teachers in schools with more advantaged pupils are better paid on average (Holmlund et al., 2014 $4_{[25]}$; Karbownik, 2014 ${ }_{[52]}$ ). More should be done to address the lack of quality teachers in schools with an unfavourable socio-economic mix of pupils (Figure 22). The status of challenging career paths in schools with an unfavourable socio-economic mix of pupils should be raised, compounding the effects of more compensatory funding to raise average results and counteract inequalities (Nye, Konstantopoulos and Hedges, 2004 [50]; André, Pareliussen and Hwang, 2019 $\left.{ }_{[7]}\right)$. 
Figure 22. Experienced teachers avoid challenging schools

Difference in the proportion of experienced teachers, challenging vs. other schools.

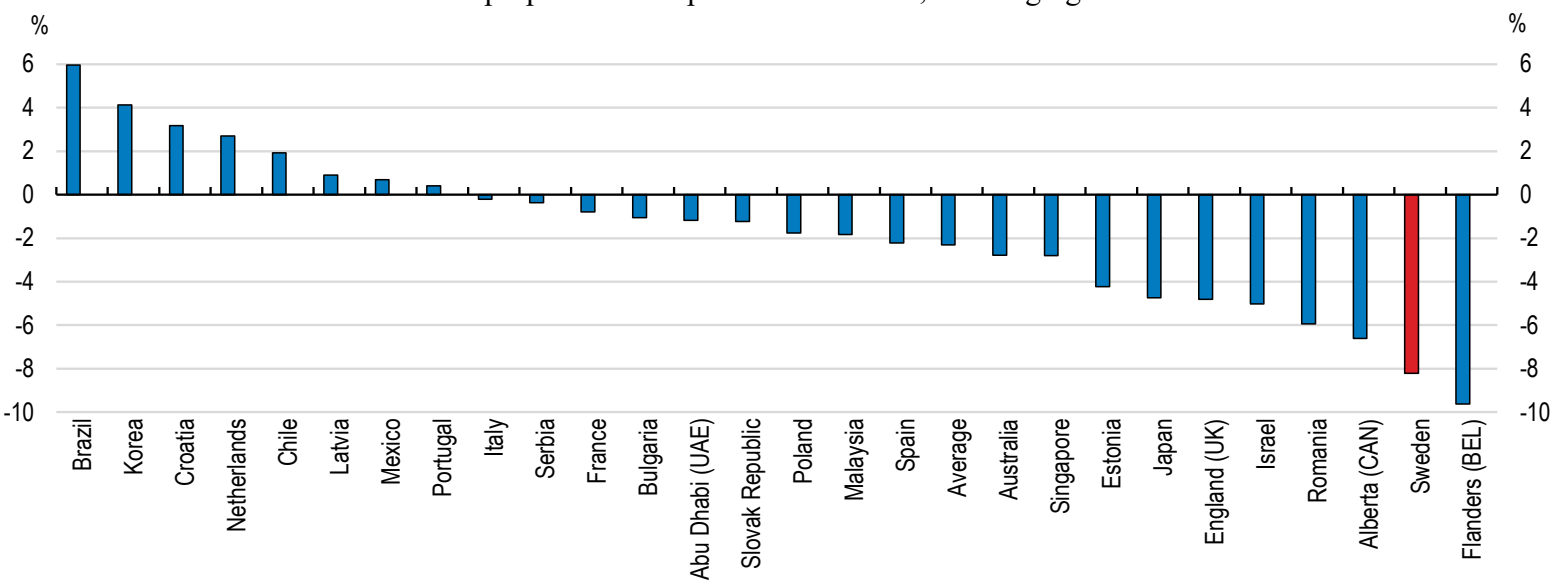

Note: Difference in the proportion of teachers with more than five years teaching experience who work in schools with more than $30 \%$ of pupils from socioeconomically disadvantaged homes and those who work in other schools.

Source: OECD, TALIS 2013 Database, Table 2.11.

StatLink जits https://doi.org/10.1787/888933944557 
Recommendations to strengthen school results and equity in the whole of Sweden

A stronger institutional set-up

Key recommendations:

- Introduce a non-binding minimum norm of school financing, integrated with the national income equalisation system, to better target funding towards disadvantaged groups.

- Develop a regional arm of the central government school governance structure tasked with systematic quality improvement, inducing local cooperation, continuous teacher training and inspections.

\section{Further recommendations:}

- Shift the responsibility of upper secondary school to the strengthened regional structure for improved governance and a better match with regional labour market demands.

- Instigate a culture of accountability where municipalities, principals and teachers assume responsibility of key outcomes.

Steer competition and choice to deliver in line with the public good

Key recommendations:

- Remove sources of bias in national test grading to create an objective benchmark for school performance, and use it to remove differences in grading leniency.

- Weigh high and low grades symmetrically and suppress the requirement to pass in certain subjects to enter upper secondary education.

- Take the socio-economic mix into account when investing in new schools and in school entry.

\section{Further recommendations:}

- Assign pupils to over-subscribed private schools by lottery, or with quotas reserved for pupils with unfavourable socio-economic backgrounds.

- Take potential effects on school segregation explicitly into account when giving permissions to open a new school, take over a school or increase pupil numbers in existing ones.

\section{Teacher quality and standing}

Key recommendations:

- Strengthen teacher education with more instruction time, teacher practice and research.

- Improve continuous learning and development through a regional school governance structure, systematic peer learning and continued mutually beneficial cooperation with universities.

\section{Further recommendation:}

- Shield principals and education personnel from unnecessary administration and red tape so they can concentrate on core teaching and leadership tasks. 


\section{Bibliography}

Anderson, K. and P. Wolf (2017), "Evaluating school vouchers: evidence from a within-study comparison”, SSRN Electronic Journal, http://dx.doi.org/10.2139/ssrn.2952967.

Andersson, C. and N. Waldenström (2007), "Teacher certification and student achievement in Swedish compulsory schools", No. 2007:6, Institute for Labour Market Policy Evaluation (IFAU), Uppsala, http://www.ifau.se.

André, C., J. Pareliussen and H. Hwang (2019), "What drives the performance of Swedish lower secondary schools?", OECD Economics Department Working Papers, forthcoming.

Auer, A. and J. Sandqvist (2016), Invandringens betydelse för skolresultaten (Immigration effects on school results), Swedish National Agency for Education, https://www.skolverket.se/sitevision/proxy/publikationer/svid12 5dfee44715d35a5cdfa2899/ 55935574/wtpub/ws/skolbok/wpubext/trycksak/Blob/pdf3604.pdf?k=3604 (accessed on 23 November 2018).

Björklund, A. et al. (2010), Den svenska utbildningspolitikens arbetsmarknadseffekter: vad säger forskningen? (Labour market effects of Swedish education policy: what does the research say), IFAU, Stockholm, http://www.ifau.se (accessed on 8 October 2018).

Böhlmark, A., H. Holmlund and M. Lindahl (2016), "Parental choice, neighbourhood segregation or cream skimming? An analysis of school segregation after a generalized choice reform", Journal of Population Economics, Vol. 29/4, pp. 1155-1190, http://dx.doi.org/10.1007/s00148-016-0595-y.

Bussi, M. and J. Pareliussen (2017), "Back to basics - Literacy proficiency, immigration and labour market outcomes in Sweden", Social Policy and Administration, Vol. 51/4, http://dx.doi.org/10.1111/spol.12319.

Cerna, L. et al. (2019), "Strength through diversity's Spotlight Report for Sweden”, OECD Education Working Papers, No. 194, OECD Publishing, Paris, https://dx.doi.org/10.1787/059ce467-en.

Cost Equalisation Commission (2018), Lite mer lika (A bit more equal), http://www.nj.se/offentligapublikationer (accessed on 9 January 2019).

Dahlstedt, M. and A. Fejes (eds.) (2018), Skolan, marknaden och framtiden (School, market and future), Studentlitteratur, Stockholm, https://www.studentlitteratur.se/\#9789144119960/Skolan,+marknaden+och+framtiden (accessed on 4 October 2018). 
Epple, D., R. Romano and R. Zimmer (2016), "Charter Schools: A Survey of Research on Their Characteristics and Effectiveness", Handbook of the Economics of Education, Vol. 5, pp. 139-208, http://dx.doi.org/10.1016/B978-0-444-63459-7.00003-8.

Glazerman, S. et al. (2013), Transfer incentives for high-performing teachers: final results from a multisite randomized experiment, https://ies.ed.gov/ncee/pubs/20144003/pdf/20144003.pdf (accessed on 22 November 2018).

Gustafsson, J., S. Sörlin and J. Vlachos (2016), Policyidéer för svensk skola (Policy ideas for Swedish schools), SNS, Stockholm, https://www.sns.se/wpcontent/uploads/2016/07/policyideer_for_svensk_skola.pdf (accessed on 2 May 2018).

Hanushek, E., J. Kain and S. Rivkin (2004), "Why public schools lose teachers", Journal of Human Resources, Vol. XXXIX/2, pp. 326-354, http://dx.doi.org/10.3368/jhr.XXXIX.2.326.

Heller Sahlgren, G. (2017), Likvärdigheten i PISA - förändringar och förklaringar (Equality in PISA - changes and explanations), Confederation of Swedish Enterprise, Stockholm, https://www.svensktnaringsliv.se/migration catalog/Rapporter_och_opinionsmaterial/Rappor ter/2131990-likvardighet_i pisa_webbpdf_682273.html/BINARY/2131990Likvardighet i_PISA webb.pdf (accessed on 8 January 2019).

Heller Sahlgren, G. and H. Jordahl (2018), Lönsamma kunskaper - sambandet mellan vinst och kvalitet i svenska grundskolor (Profitable knowledge - relationship between profits and quality in Swedish compulsory schools), Confederation of Swedish Enterprise, Stockholm, https://www.ifn.se/publikationer/publicerade-artiklar-pa-svenska/2018/2018-10 (accessed on 12 October 2018).

Holmlund, H. et al. (2014), Decentralisering, skolval och fristående skolor: resultat och likvärdighet i svensk skola (Decentralisation, school choice and private schools: results and equality in Swedish schools), IFAU, Stockholm, http://www.ifau.se (accessed on 31 August 2018).

Karbownik, K. (2014), "Do changes in student quality affect teacher mobility? Evidence from an admission reform", IFAU Working Paper Series, https://ideas.repec.org/p/hhs/ifauwp/2014 015.html (accessed on 8 October 2018).

Krauss, S. et al. (2008), "Pedagogical content knowledge and content knowledge of secondary mathematics teachers.", Journal of Educational Psychology, Vol. 100/3, pp. 716-725, http://dx.doi.org/10.1037/0022-0663.100.3.716.

Malmberg, B., E. Andersson and Z. Bergsten (2014), “Composite Geographical Context and School Choice Attitudes in Sweden: A Study Based on Individually Defined, Scalable Neighborhoods", Annals of the Association of American Geographers, Vol. 104/4, pp. 869888, http://dx.doi.org/10.1080/00045608.2014.912546.

Mellander, C. and L. Bjerke (2017), "De ungas flykt till staden (The young's flight to the city)", in Syssner, J., S. Häggroth and U. Ramberg (eds.), Att äga framtiden: Perspektiv på kommunal utveckling, Linköping University Electronic Press, 2017. p. 195-201, http://hj.divaportal.org/smash/get/diva2:1167412/FULLTEXT01.pdf (accessed on 17 September 2018). 
Ministry of Education and Research (2016), Regeringens insatser inom området matematik (The government's actions within the mathematics area), https://www.regeringen.se/artiklar/2016/11/regeringens-insatser-inom-omradet-matematikett-av-de-amnesomraden-som-mats-i-timss-timss-advanced-och-pisa/.

Nye, B., S. Konstantopoulos and L. Hedges (2004), How large are teacher effects?, https://steinhardt.nyu.edu/scmsAdmin/uploads/002/834/127\%20$\% 20$ Nye $\% 20 \mathrm{~B} \% 20 \% 20$ Hedges $\% 20 \mathrm{~L} \% 20 \% 20 \mathrm{~V} \% 20 \% 20 \% 20$ Konstantopoulos $\% 20 \mathrm{~S} \% 20 \% 2$ 0(2004).pdf (accessed on 8 October 2018).

OECD (2018), Education at a glance database, https://www.oecdilibrary.org/education/data/education-at-a-glance eag-data-en (accessed on 2 October 2018).

OECD (2018), OECD Economic Surveys: Chile 2018, OECD Publishing, Paris, http://dx.doi.org/10.1787/eco surveys-chl-2018-en.

OECD (2017), OECD Economic Surveys: Sweden 2017, OECD Publishing, Paris, http://dx.doi.org/10.1787/eco surveys-swe-2017-en.

OECD (2017), School choice and school vouchers: An OECD perspective, http://www.oecd.org/education/School-choice-and-school-vouchers-an-OECDperspective.pdf (accessed on 18 February 2019).

OECD (2017), School choice and school vouchers: An OECD perspective, OECD Publishing, Paris, http://www.oecd.org (accessed on 18 February 2019).

OECD (2016), OECD Review of policies to improve the effectiveness of resource use in schools (School resources review) Czech Republic, OECD, Paris, http://www.oecd.org/education/schoolresourcesreview (accessed on 2 October 2018).

OECD (2016), OECD reviews of school resources. Denmark 2016, OECD Publishing, Paris.

OECD (2016), PISA 2015 results (Volume I): excellence and equity in education, PISA, OECD Publishing, Paris, http://dx.doi.org/10.1787/9789264266490-en.

OECD (2016), PISA 2015 results (Volume II): policies and practices for successful schools, PISA, OECD Publishing, Paris, http://dx.doi.org/10.1787/9789264267510-en.

OECD (2015), Improving schools in Sweden: an OECD perspective, http://www.oecd.org/education/school/Improving-Schools-in-Sweden.pdf (accessed on 2 May 2018).

OECD (2015), OECD Economic Surveys: Sweden 2015, OECD Publishing, Paris, http://dx.doi.org/10.1787/eco surveys-swe-2015-en.

OECD (2014), TALIS 2013 results: an international perspective on teaching and learning, TALIS, OECD Publishing, Paris, http://dx.doi.org/10.1787/9789264196261-en.

OECD (1992), Review of education policy in Sweden, OECD, Paris. 
Pareliussen, J. et al. (2018), "Income inequality in the Nordics from an OECD perspective", in Calmfors, L. and J. Roine (eds.), Nordic Economic Policy Review 2018, Increasing Income Inequality in the Nordics, Nordic Council of Ministers, http://dx.doi.org/10.6027/TN2018$\underline{519}$ (accessed on 23 May 2018).

Persson, E. (2013), "Raising achievement through inclusion", International Journal of Inclusive Education, Vol. 17/11, pp. 1205-1220, http://dx.doi.org/10.1080/13603116.2012.745626.

School Commission (2017), Samling för skolan - Nationell strategi för kunskap och likvärdighet (Together for schools - National strategy for knowledge and equality), http://www.regeringen.se/498092/contentassets/e94a1c61289142bfbcfdf54a44377507/samlin g-for-skolan---nationell-strategi-for-kunskap-och-likvardighet-sou-201735.pdf (accessed on 2 May 2018).

SKL (2018), Ekonomirapporten, maj 2018 (The economic report, May 2018), Swedish Association of Local Authorities and Regions, Stockholm, https://webbutik.skl.se/bilder/artiklar/pdf/7585-541-7.pdf (accessed on 5 October 2018).

SKL and MoF (2008), Local government financial equalisation Information about the equalisation system for Swedish municipalities and county councils in 2008, Swedish Association of Local Authorities and Regions and Swedish Ministry of Finance, Stockholm, http://www.sweden.gov.se (accessed on 22 November 2018).

Skolverket (2018), Analyser av familjebakgrundens betydelse för skolresultaten och skillnader mellan skolor (Analyses of family backgrounds influence of school results and differences between schools), Swedish National Agency of Education, Stockholm, https://www.skolverket.se/sitevision/proxy/publikationer/svid12 5dfee44715d35a5cdfa2899/ 55935574/wtpub/ws/skolbok/wpubext/trycksak/Blob/pdf3927.pdf?k=3927 (accessed on 18 September 2018).

Skolverket (2017), Beskrivande data 2017, Förskola, skola och vuxenutbildning (\&quot;Descriptive data 2017, Pre-school, school and adult education\&quot;), Swedish Agency of Education, Stockholm, https://www.skolverket.se/sitevision/proxy/publikationer/svid12 5dfee44715d35a5cdfa2899/ 55935574/wtpub/ws/skolbok/wpubext/trycksak/Blob/pdf3953.pdf?k=3953 (accessed on 27 September 2018).

Statistics Sweden (2018), Befolkningsstatistik (Population statistics), https://www.scb.se/hittastatistik/statistik-efter-amne/befolkning/befolkningens-sammansattning/befolkningsstatistik/ (accessed on 23 November 2018).

Statistics Sweden (2018), Lokala arbetsmarknader (Local labour market regions), https://www.scb.se/hitta-statistik/statistik-efter-amne/arbetsmarknad/sysselsattningforvarvsarbete-och-arbetstider/registerbaserad-arbetsmarknadsstatistik-

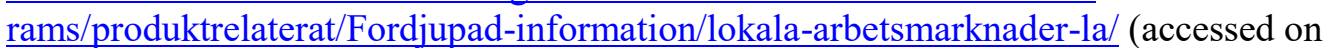
30 August 2018).

Sund, K. (2009), "Estimating peer effects in Swedish high school using school, teacher, and student fixed effects", Economics of Education Review, Vol. 28/3, pp. 329-336, http://dx.doi.org/10.1016/J.ECONEDUREV.2008.04.003. 
Sveriges Riksdag (2010), Skollagen (the Education Act) 2010:800, http://www.riksdagen.se/sv/dokument-lagar/dokument/svensk-forfattningssamling/skollag2010800 sfs-2010-800.

Sveriges Riksdag (1985), Skollagen (the Education Act) 1985:1100, http://www.riksdagen.se/sv/dokument-lagar/dokument/svensk-forfattningssamling/skollag19851100 sfs-1985-1100.

Swedish Labour Policy Council (2016), Dags för större lönespridning? (Time for more wage dispersion?), Swedish Labour Policy Council, Stockholm, http://www.arbetsmarknadsekonomiskaradet.se/rapporter/.

Urquiola, M. (2016), "Competition Among Schools: Traditional Public and Private Schools", Handbook of the Economics of Education, Vol. 5, pp. 209-237, http://dx.doi.org/10.1016/B978-0-444-63459-7.00004-X.

Vlachos, J. (2018), "Trust-based evaluation in a market-oriented school system", No. 1217, IFN, Stockholm, https://www.ifn.se/publikationer/working_papers/2018/1217 (accessed on 5 June 2018).

Werne, K. (2018), Skolindustrin, Hur mångfald blev enfald (The school industry, how diversity became singularity), Swedish Trade Union Confederation (LO), Stockholm, https://www.lo.se/home/lo/res.nsf/vRes/lo fakta_1366027478784_skolindustrin_pdf/\$File/Sk olindustrin.pdf (accessed on 12 October 2018).

Wondratschek, V., K. Edmark and M. Frölich (2013), The short-and long-term effects of school choice on student outcomes-Evidence from a school choice reform in Sweden, https://www.jstor.org/stable/pdf/23646327.pdf?refreqid=excelsior\%3Aa335cb8a84f37e0896b 58a9b1018c305 (accessed on 31 August 2018).

Yang Hansen, K. and J. Gustafsson (2016), "Causes of educational segregation in Sweden school choice or residential segregation", Educational Research and Evaluation, Vol. 22/1-2, http://dx.doi.org/10.1080/13803611.2016.1178589. 